
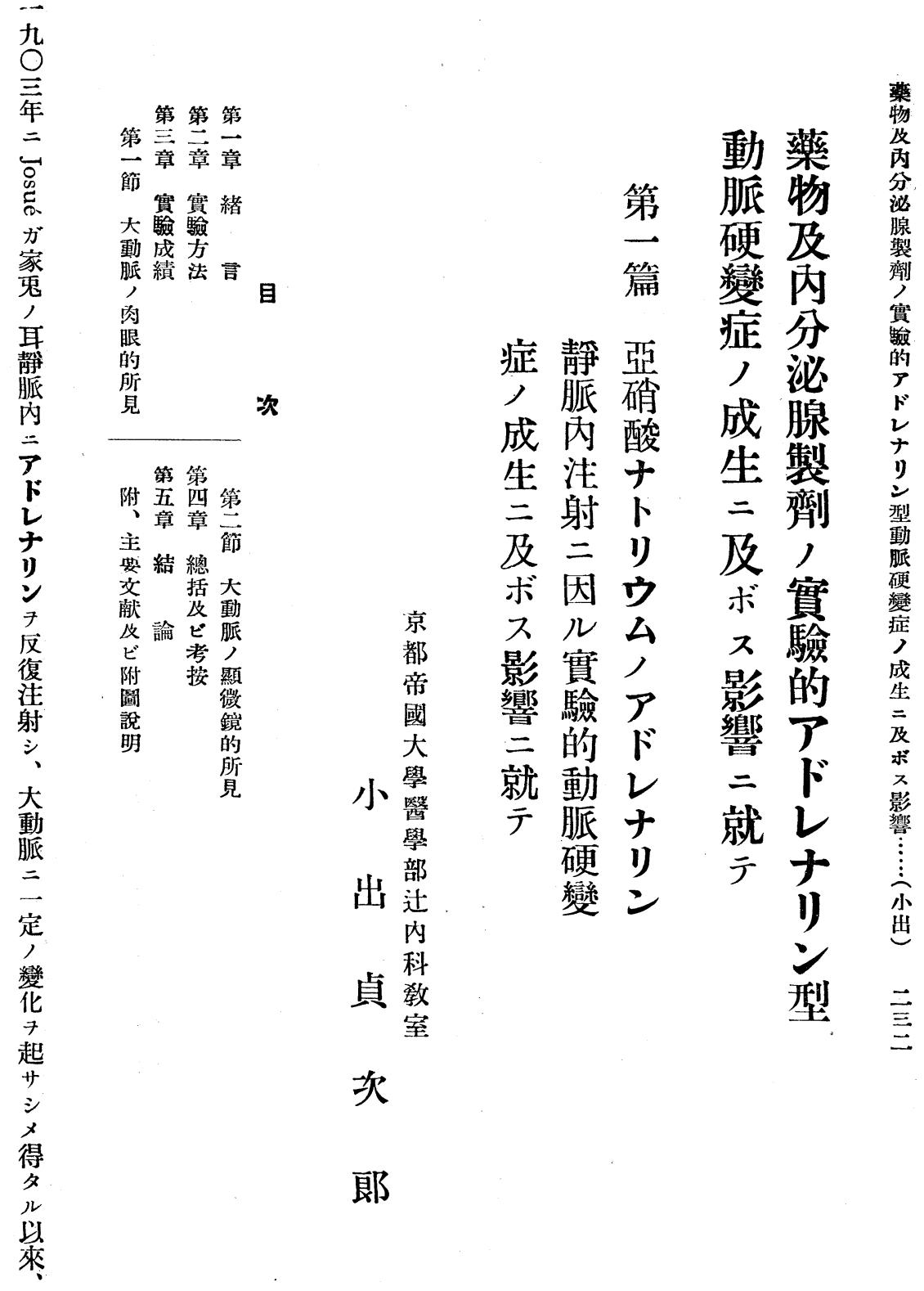

次

郎 


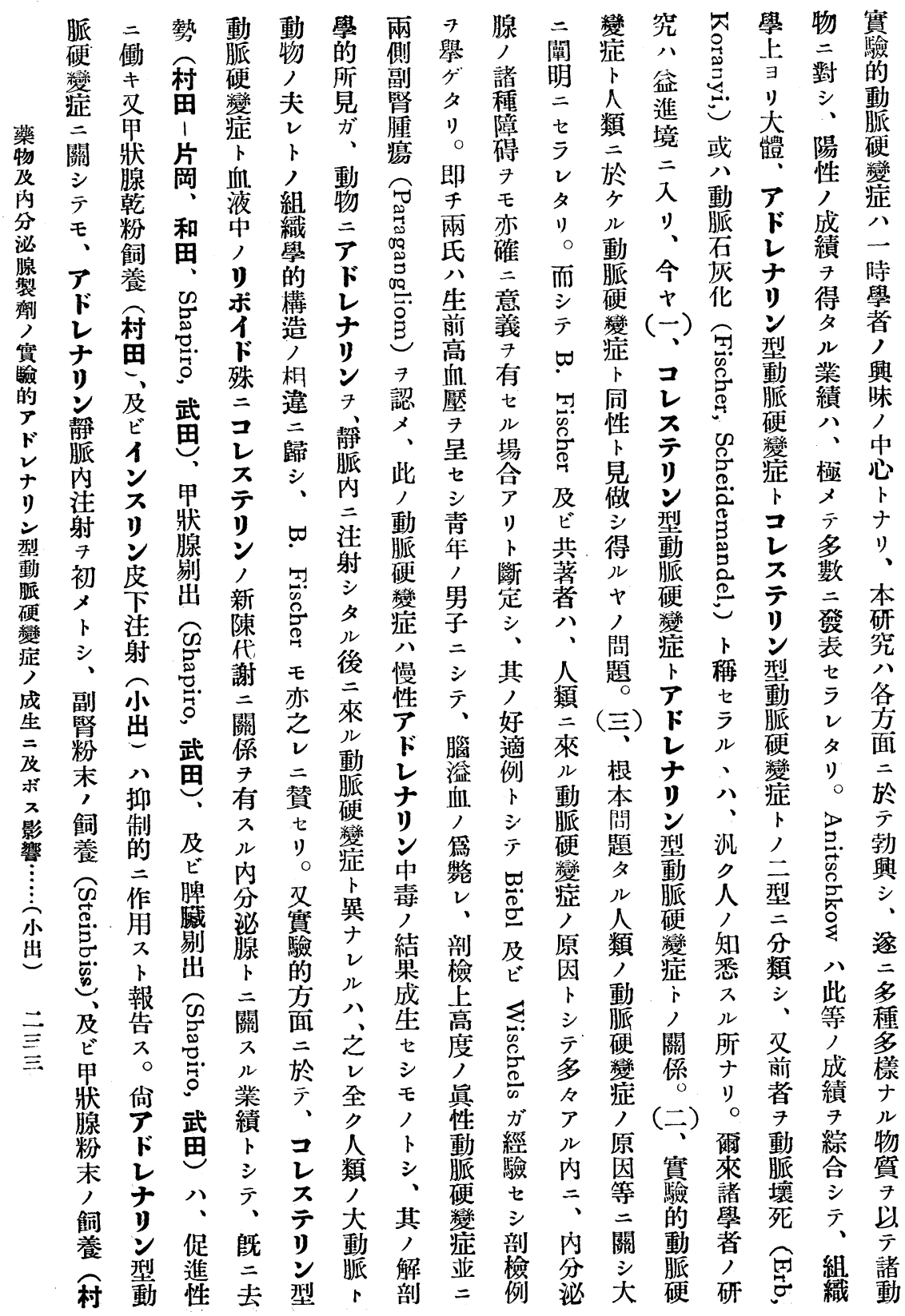




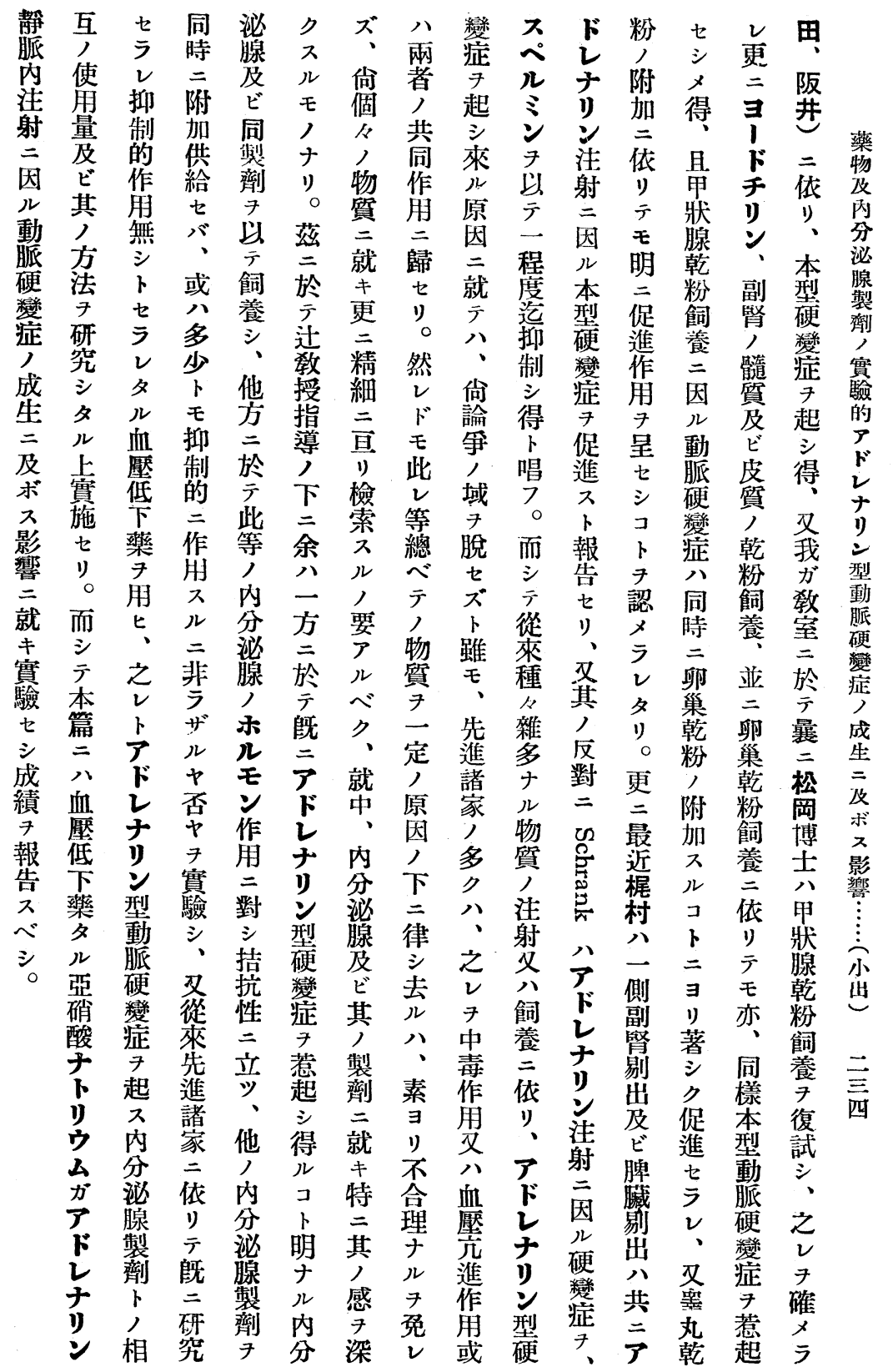




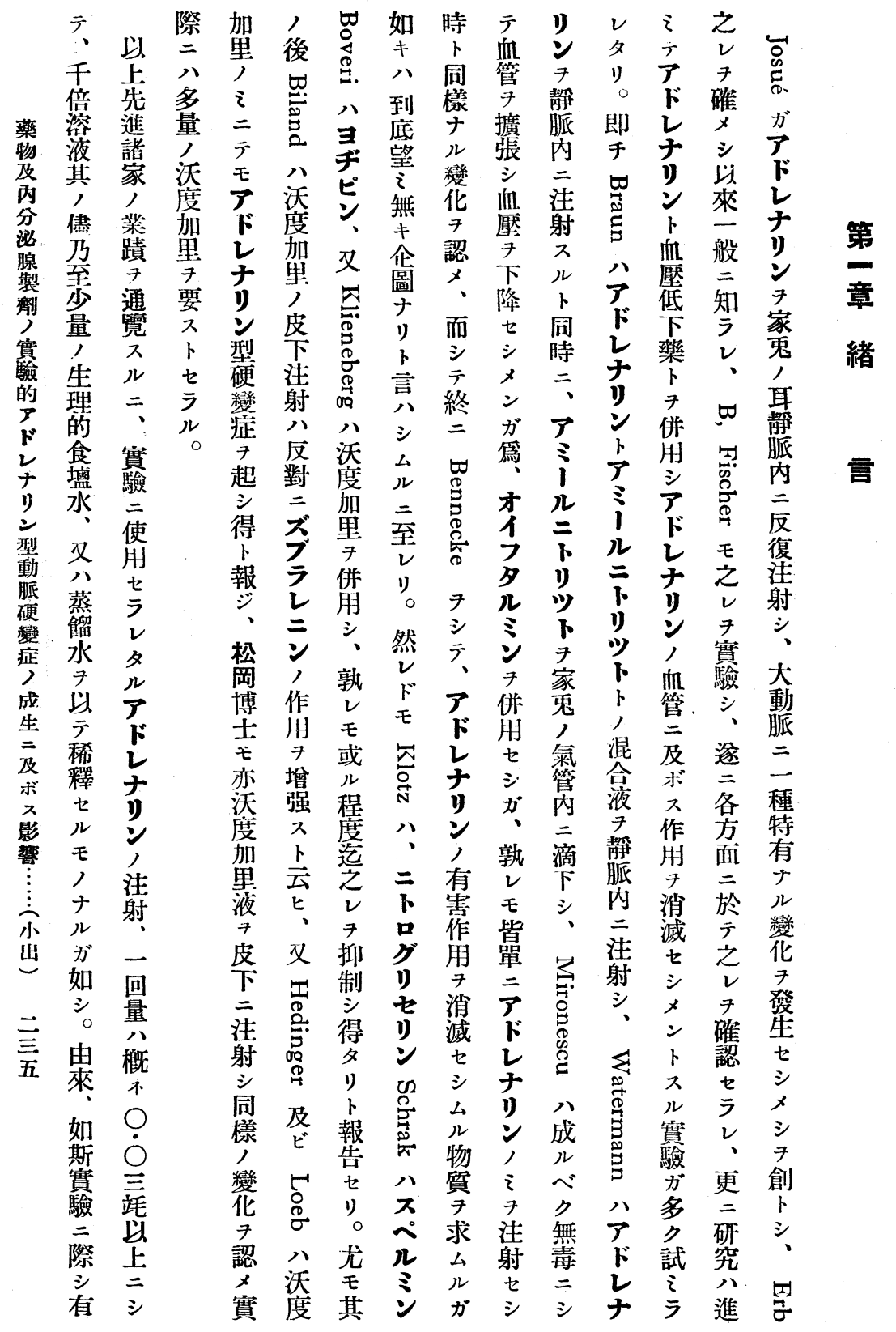




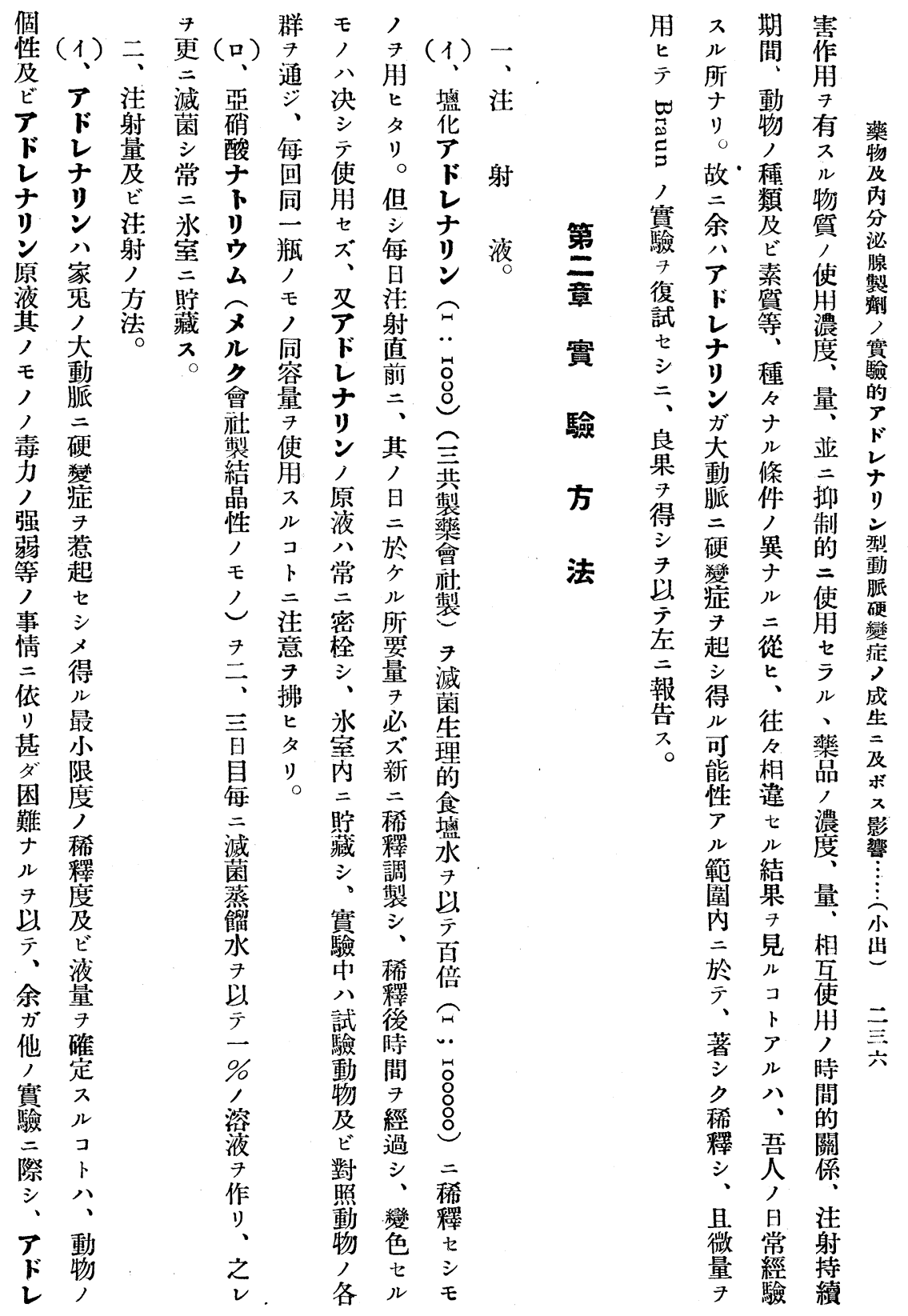




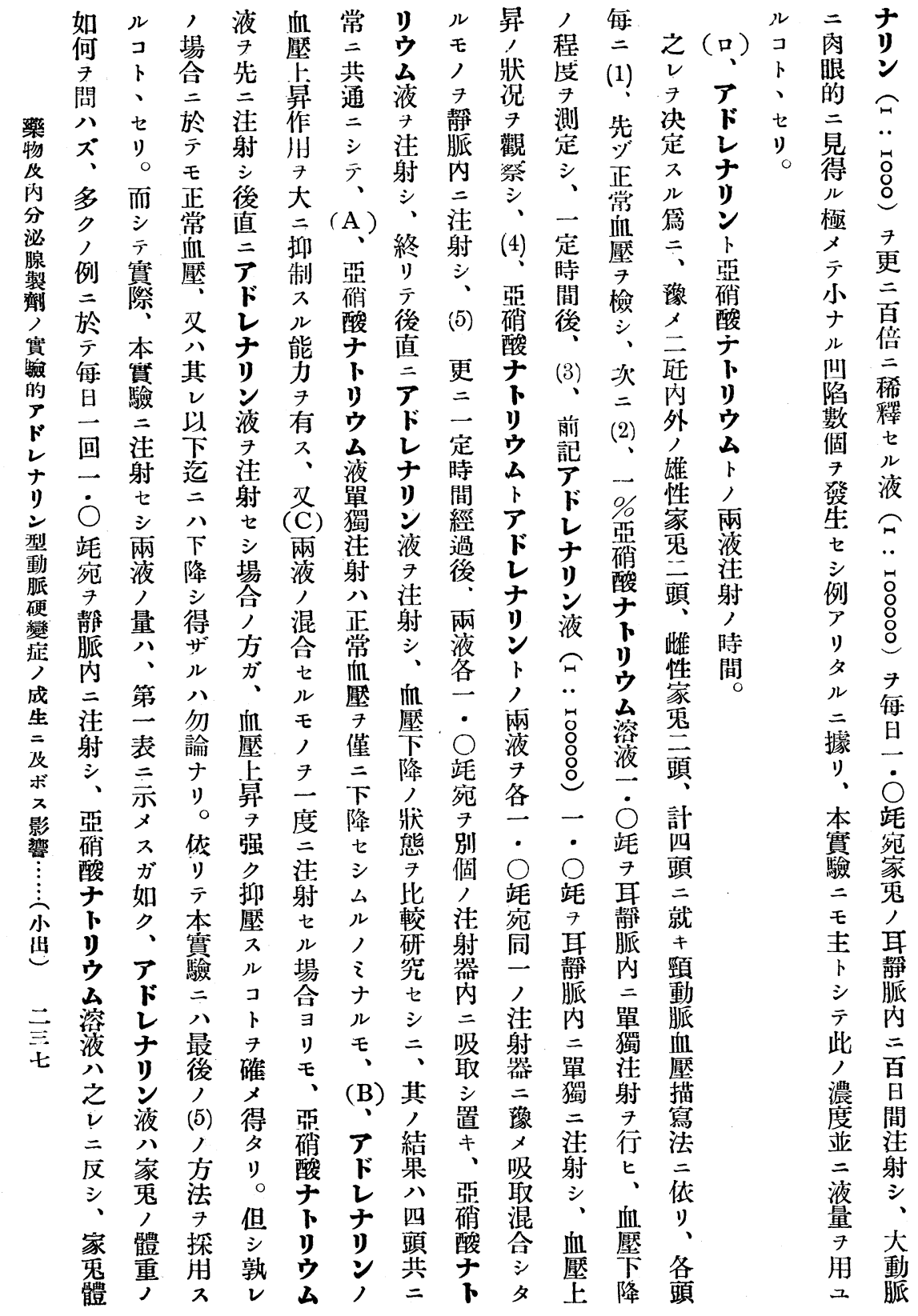




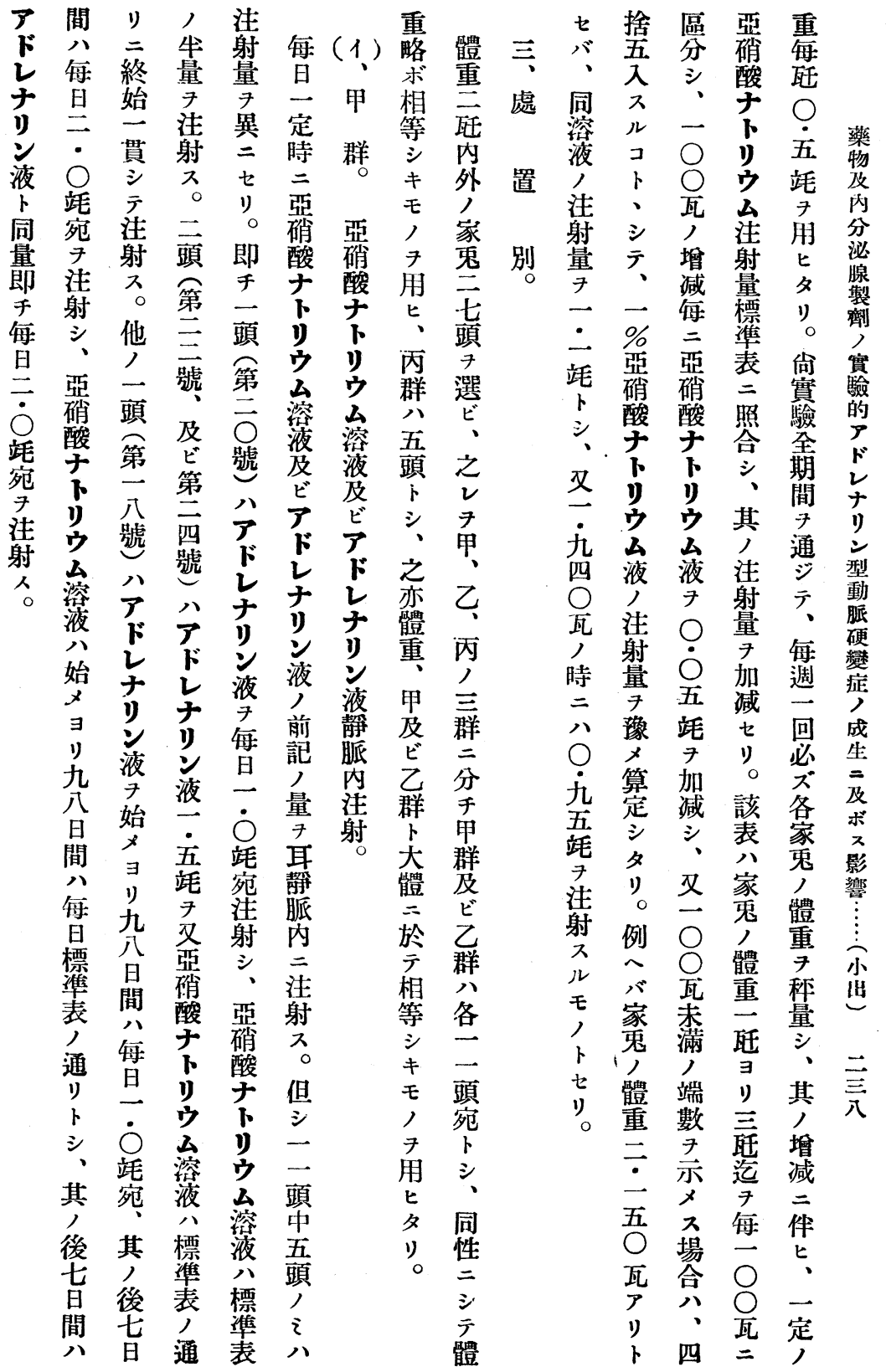




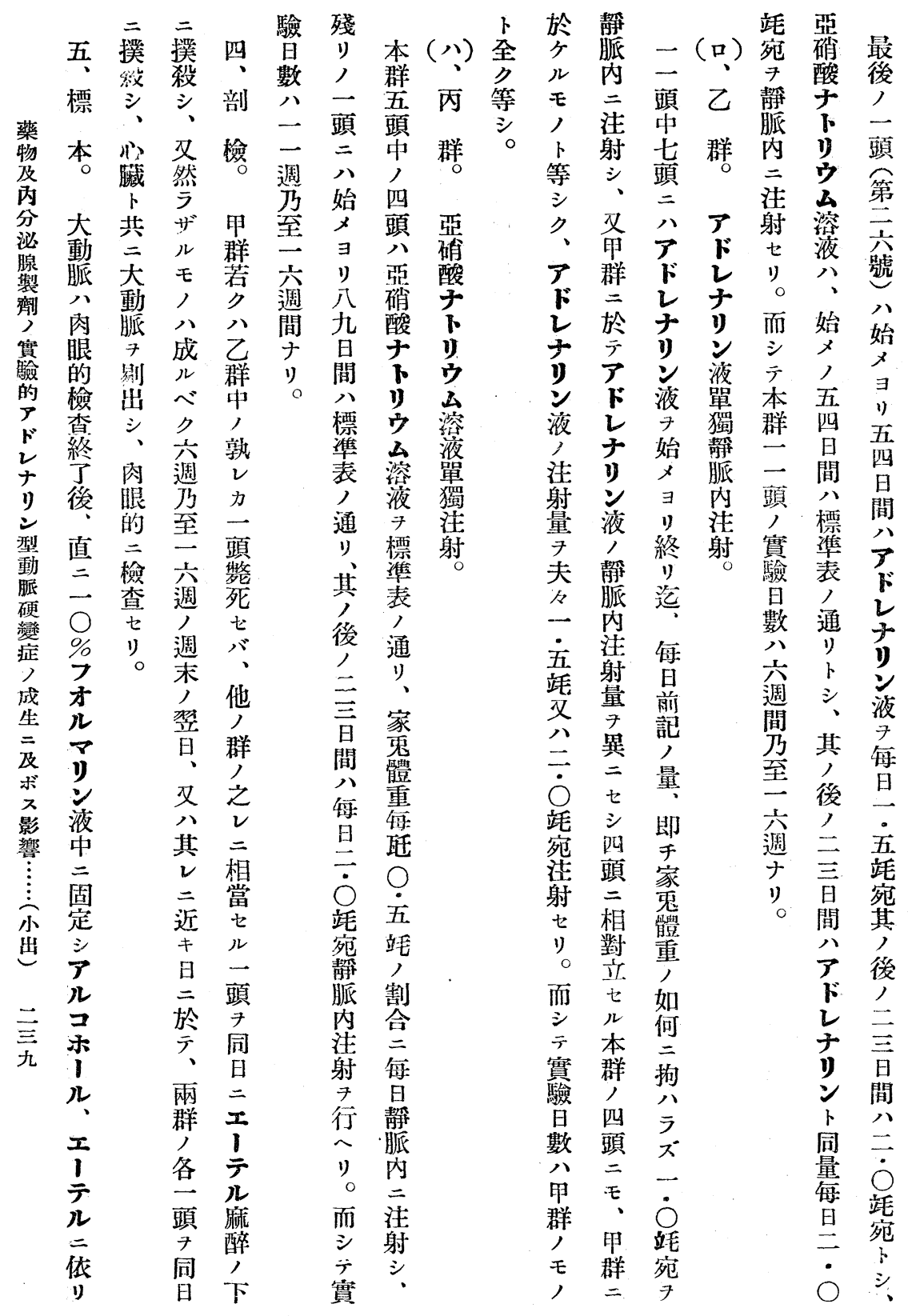




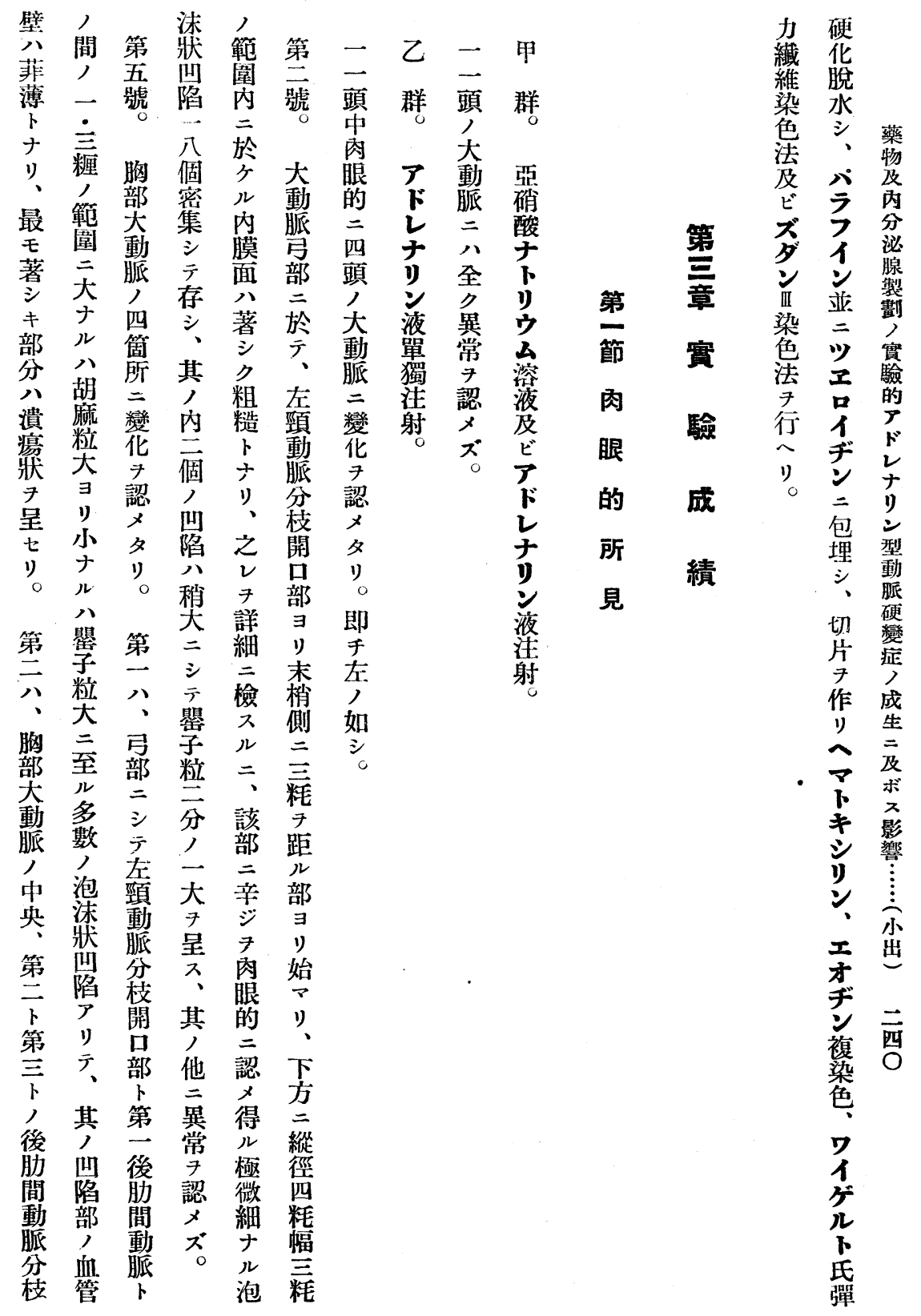




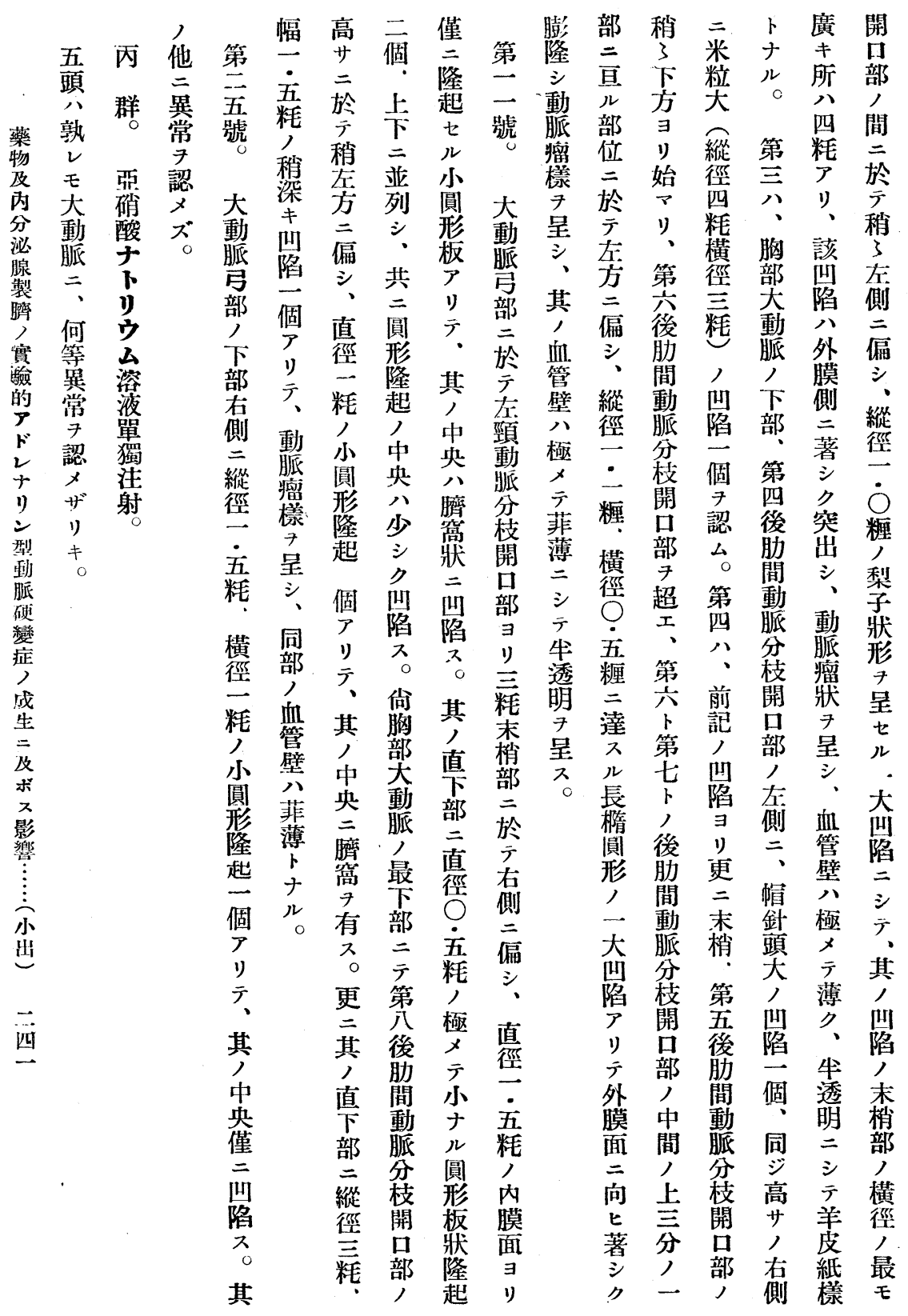




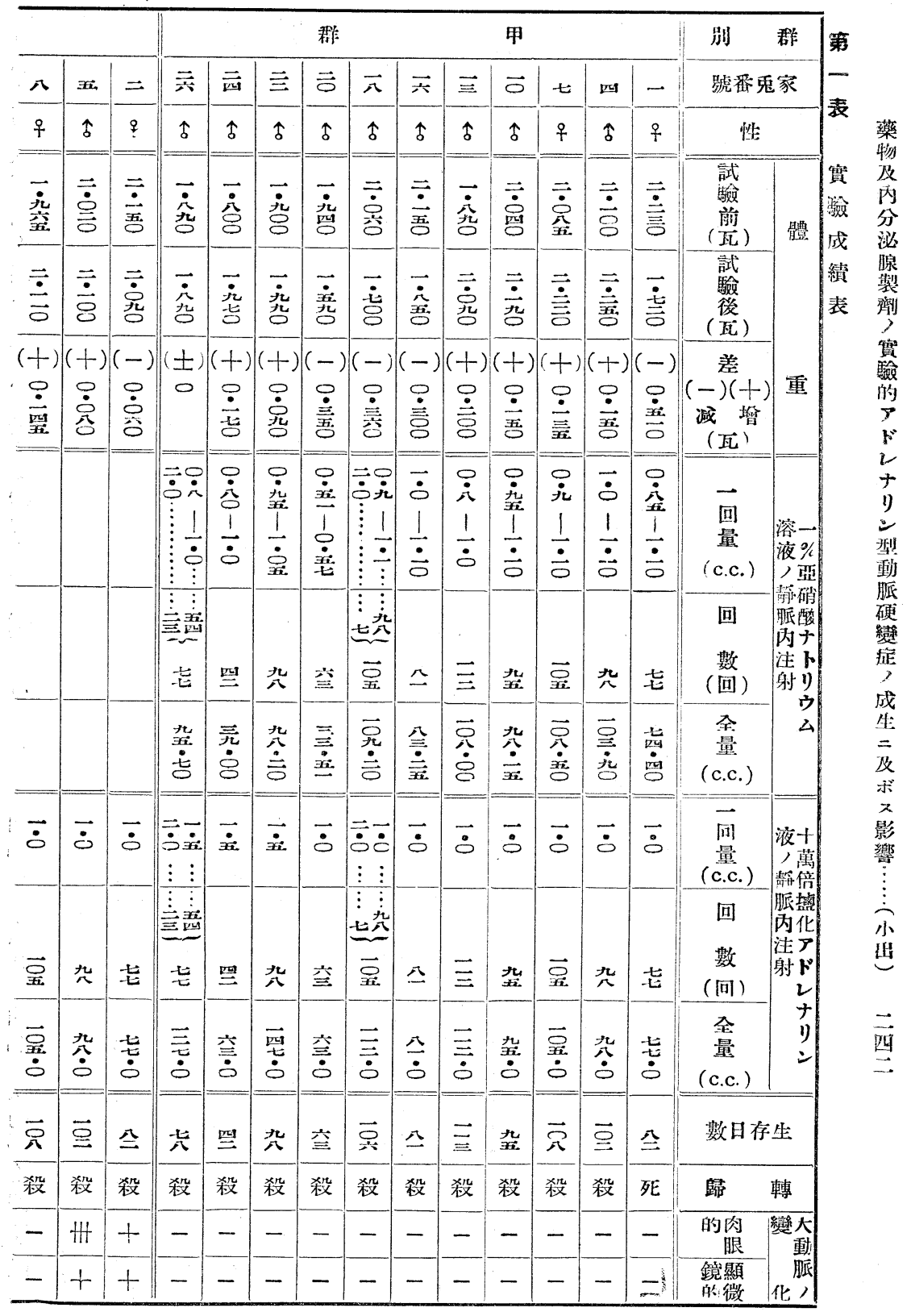




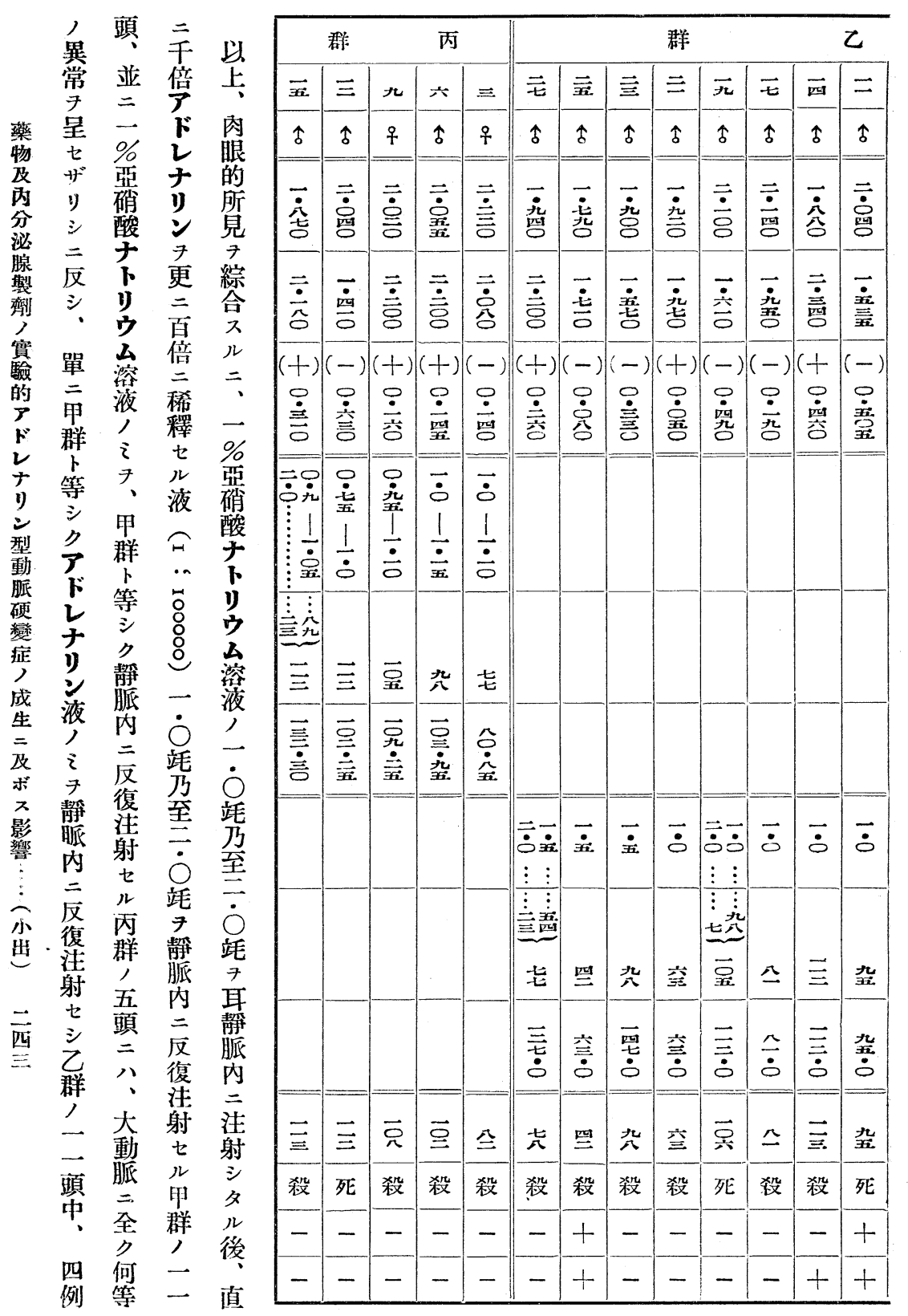




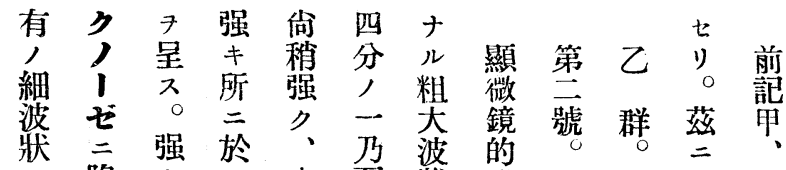

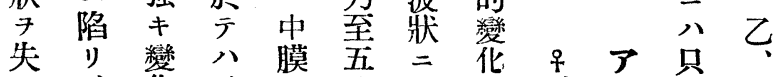

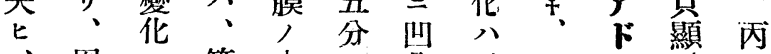

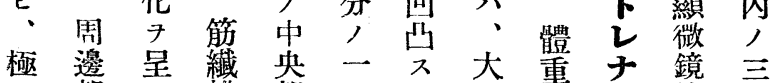

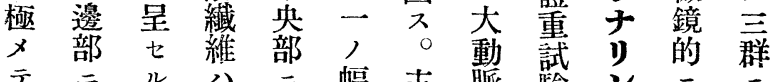

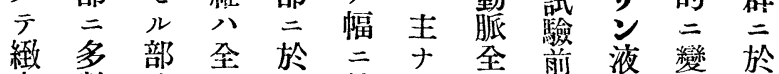

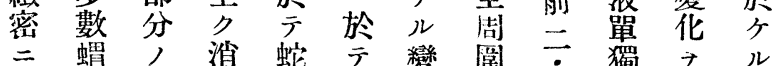

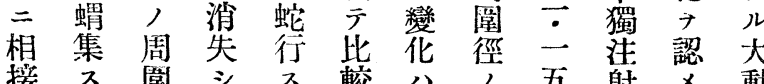

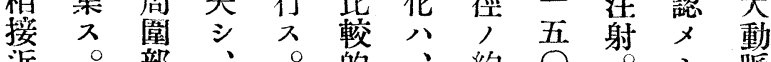

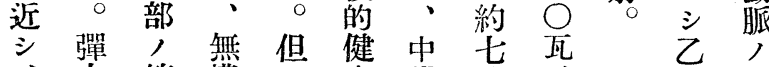

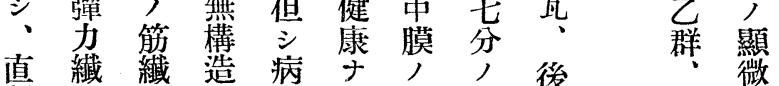
真 瀻 㵶 造

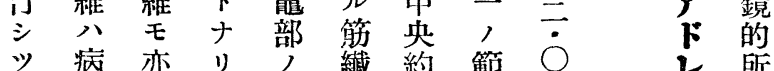

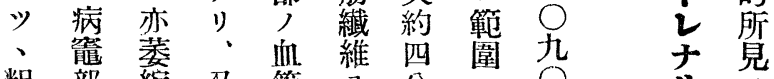
粗 部絔 又管 分

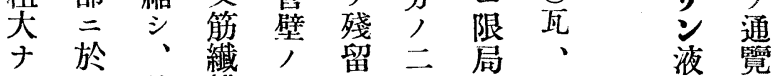

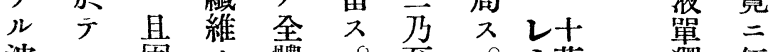

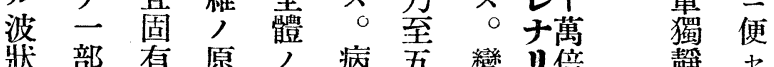

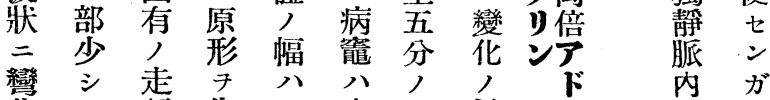

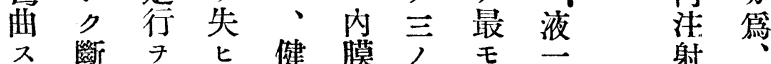
ス 裂失

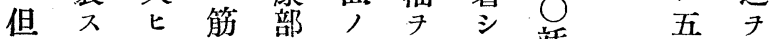

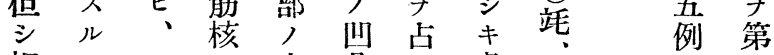
想モ、般膨夫

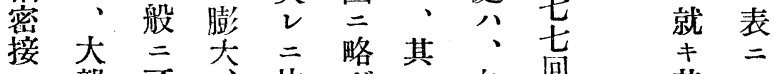
七部不、比条了血回其二 分賛淡音普内管㴬方括 反八則染 狹行膜腔射 所揭 對其卜三小侧罂載 側㶵りナカ ナ ル 及 彈 殘。方 力留 筋 $\Rightarrow$ 。䇾膜

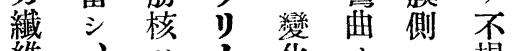
維、分化, 二 瞡 特ピセ, 度各則

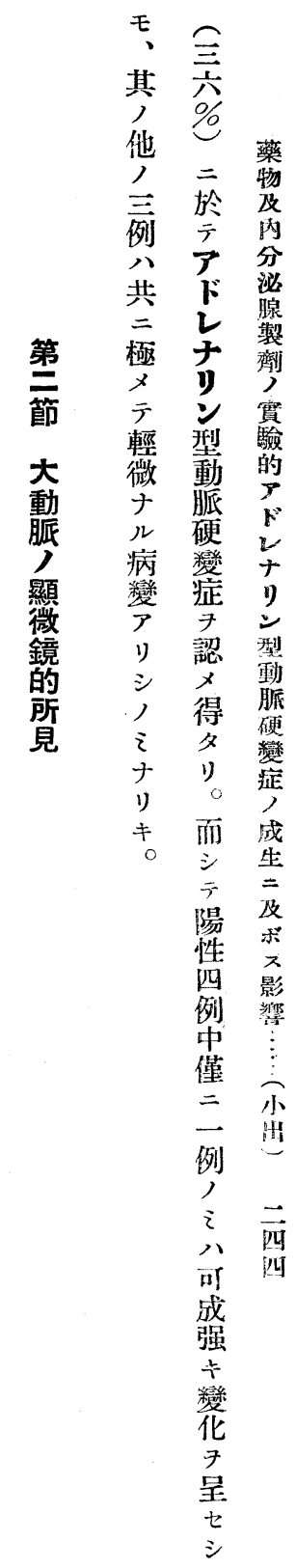




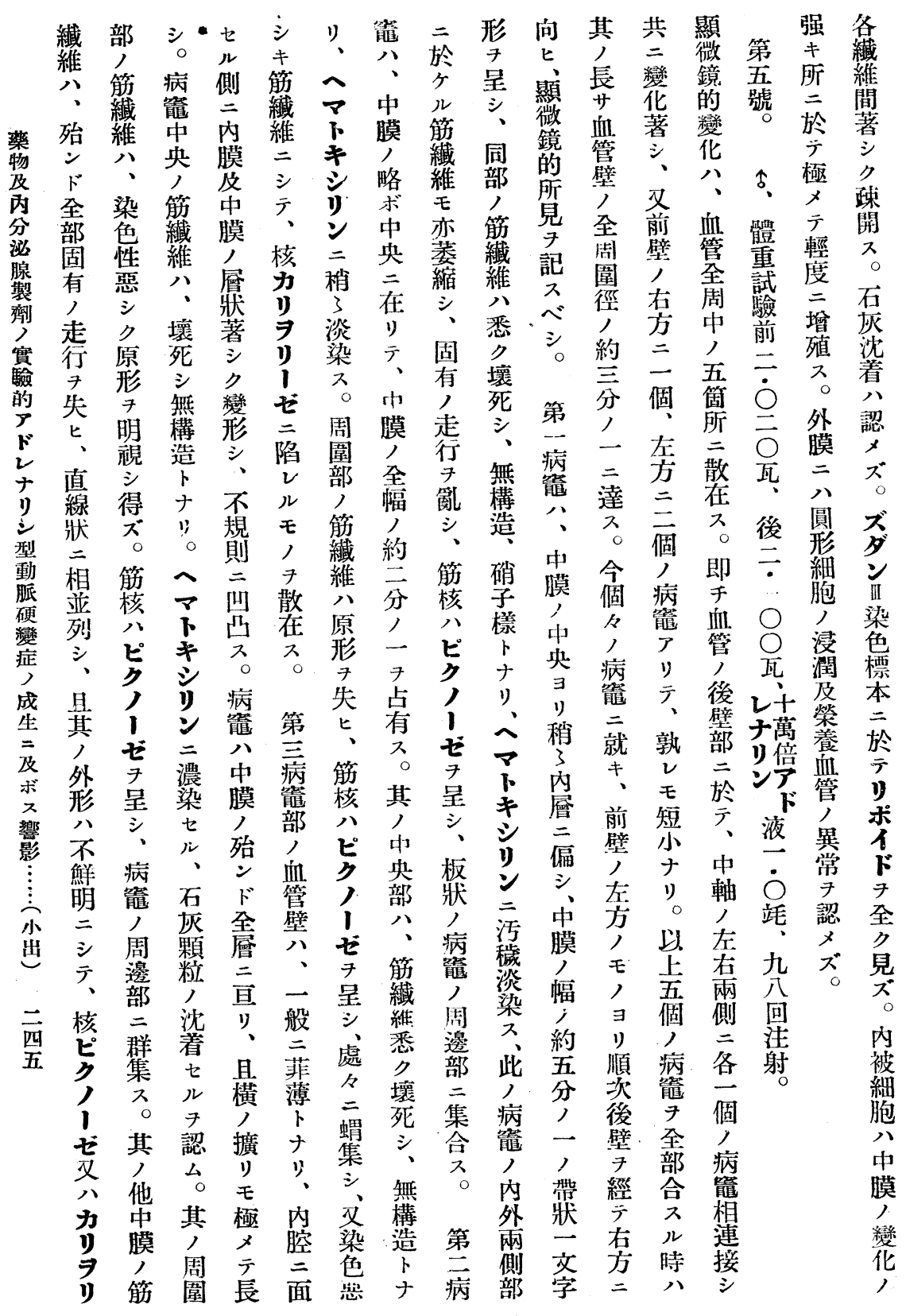




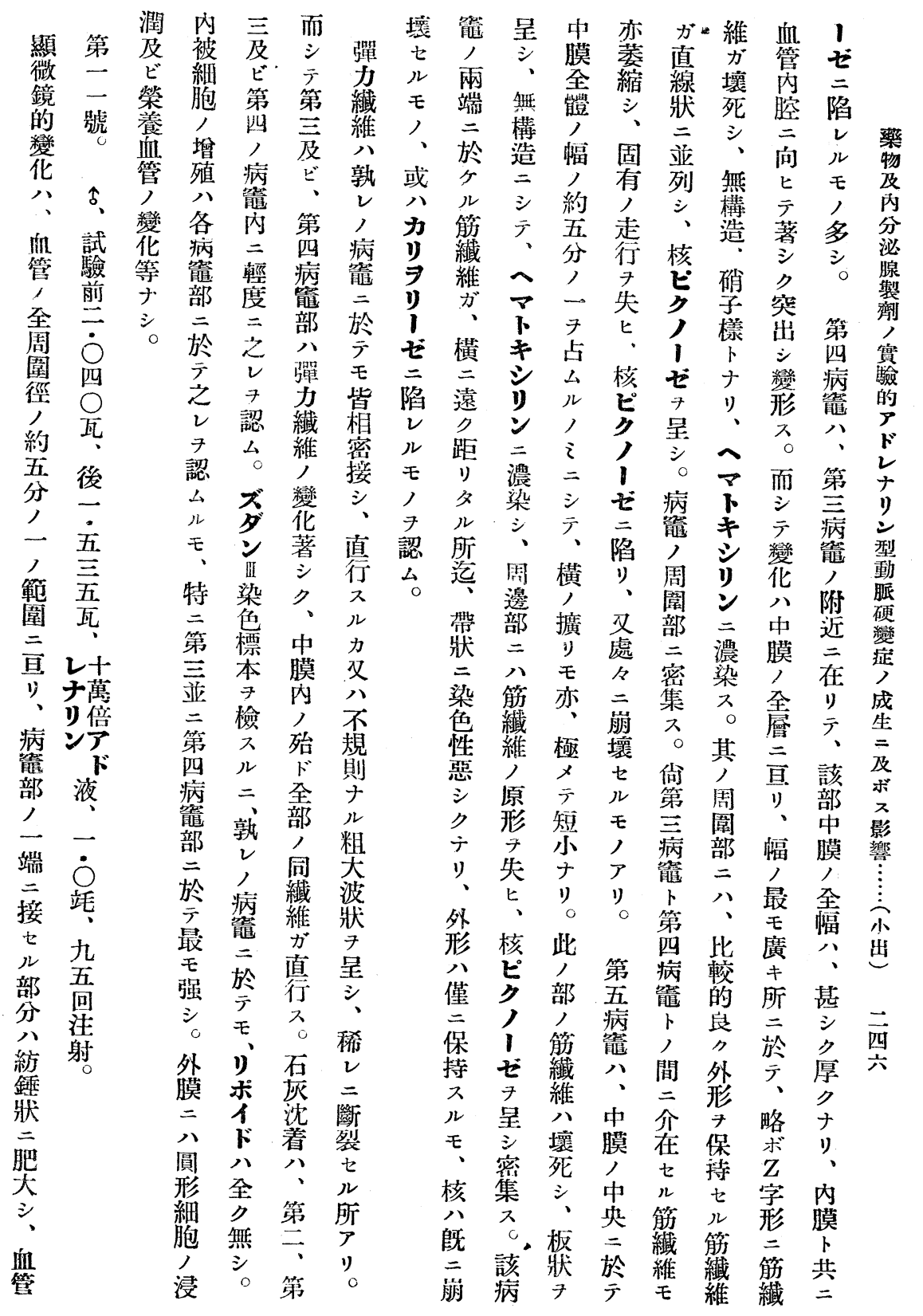




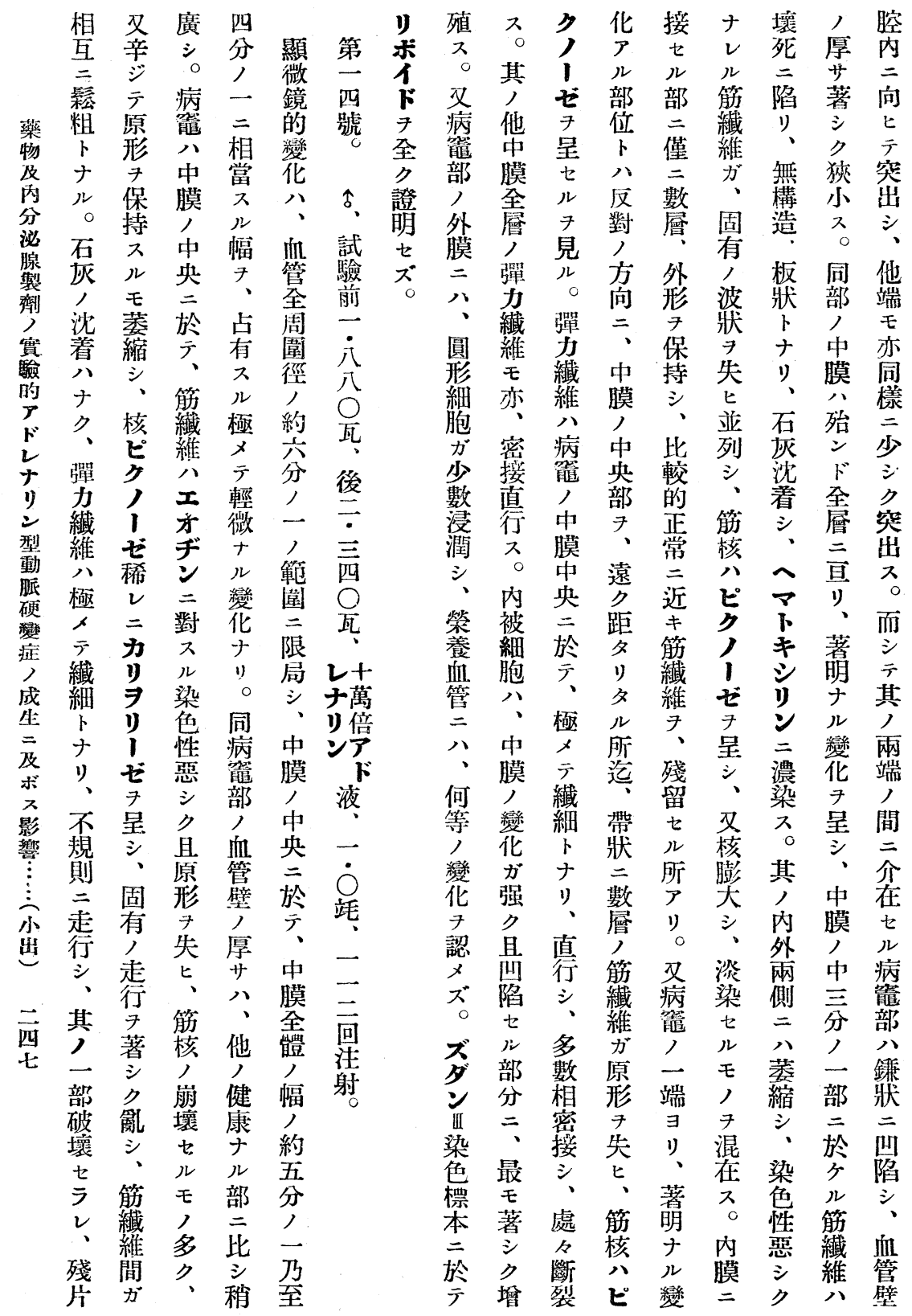




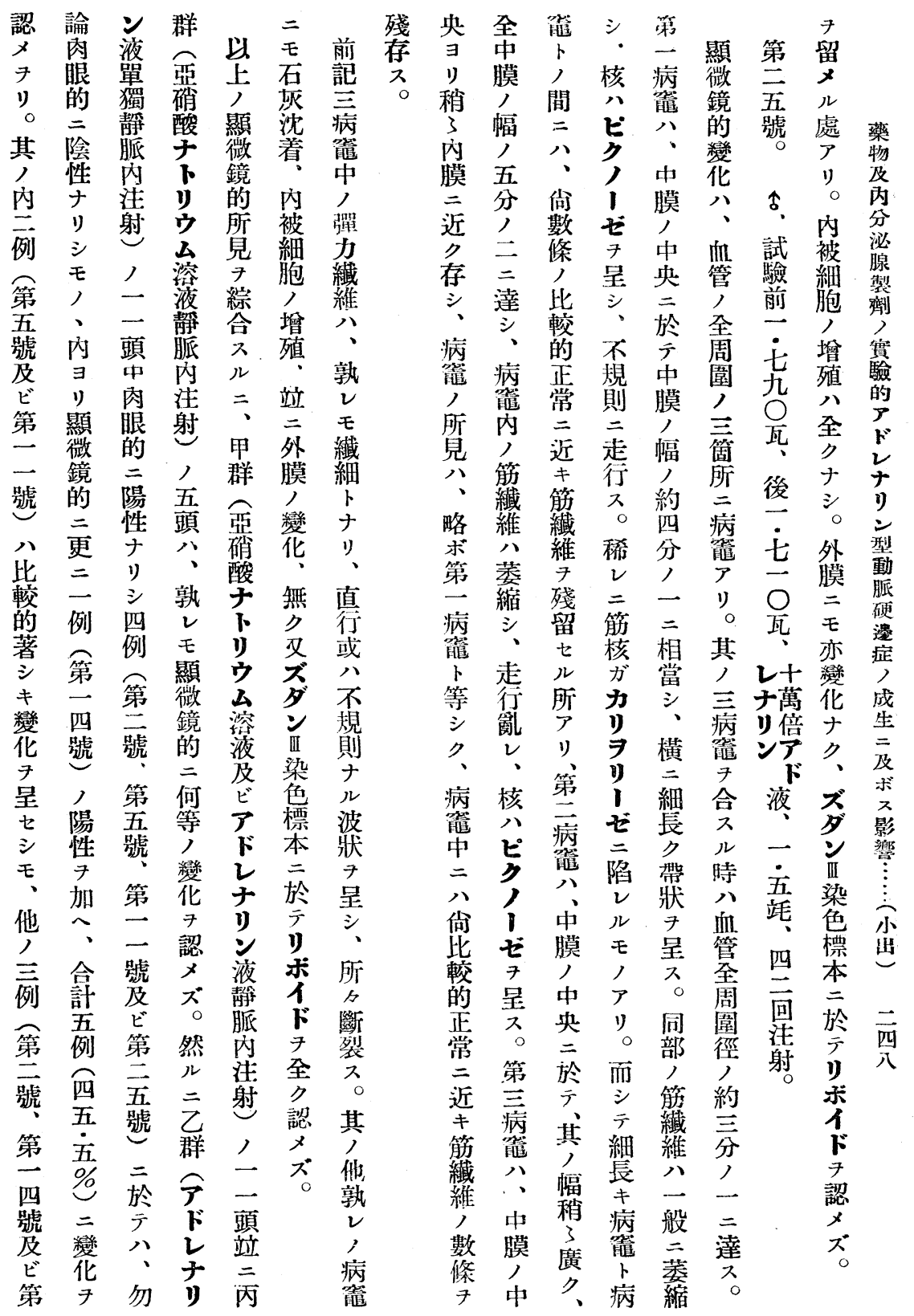




\begin{tabular}{|c|c|c|c|c|c|c|c|}
\hline 組六第 & 組 五第 & 組 四第 & 組三第 & 組二第 & 組一第 & 别 & 組 \\
\hline 乙甲 & 丙乙甲 & 两乙甲 & 两乙甲 & 丙乙甲 & 丙乙甲 & 别 & 群 \\
\hline $\begin{array}{l}\vec{E} \\
\vec{t} \\
\text { 號 }\end{array}$ & 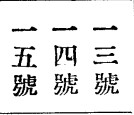 & 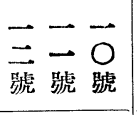 & $\begin{array}{lll}\text { 九 } & \text { 七 } \\
\text { 號 號 } & \text { 號 }\end{array}$ & $\begin{array}{c}\text { 六五 四 } \\
\text { 號 號 號 } \\
\end{array}$ & $\begin{array}{l}\equiv \text { 三一 } \\
\text { 號 號 躆 } \\
\end{array}$ & 號 番 & \multirow{2}{*}{$\begin{array}{l}\text { 家 } \\
\text { 鬼 }\end{array}$} \\
\hline$\hat{\delta} \boldsymbol{\delta}$ & $\begin{array}{lll}\hat{\delta} & \hat{\delta} & \hat{\delta} \\
\end{array}$ & $\delta \hat{\delta} \delta$ & ㅇ $\quad+\quad+$ & $\hat{\delta} \quad \hat{\delta} \quad \hat{\delta}$ & ㅇ $\quad+\quad+$ & 性 & \\
\hline-- & --- & -+- & --- & -+- & -+- & $\begin{array}{r}\text { 殖胞內 } \\
\text { 被 } \\
\text { 增細 } \\
\end{array}$ & 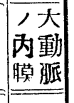 \\
\hline-- & -+- & -+- & --- & -+- & -+- & 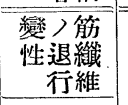 & 大 \\
\hline-- & --- & -+- & --- & -+- & --- & $\begin{array}{l}\text { 沈石 } \\
\text { 着灰 }\end{array}$ & $\begin{array}{l}\text { 動 } \\
\text { 脈 }\end{array}$ \\
\hline-- & -+- & -+- & --- & -+- & -+- & 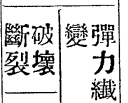 & $\begin{array}{l}> \\
\text { 中 }\end{array}$ \\
\hline-- & -+- & -+- & --- & -+- & -+- & \begin{tabular}{|c|c|} 
真 & 維 \\
\end{tabular} & 膜 \\
\hline-- & -- & -+- & --- & --- & --- & $\begin{array}{l}\text { 浸細 } \\
\text { 潤胞 }\end{array}$ & $\begin{array}{l}\text { 憅 } \\
\text { 脤 }\end{array}$ \\
\hline-- & --- & --- & -- & --- & --- & 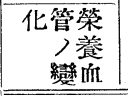 & $\begin{array}{l}\text { 外 } \\
\text { 臈 } \\
\end{array}$ \\
\hline-- & -+- & $-H-$ & --- & $-H-$ & -+- & $\begin{array}{l}\text { 分的 } \\
\text { 程變 } \\
\text { 鹿化金 }\end{array}$ & 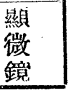 \\
\hline
\end{tabular}

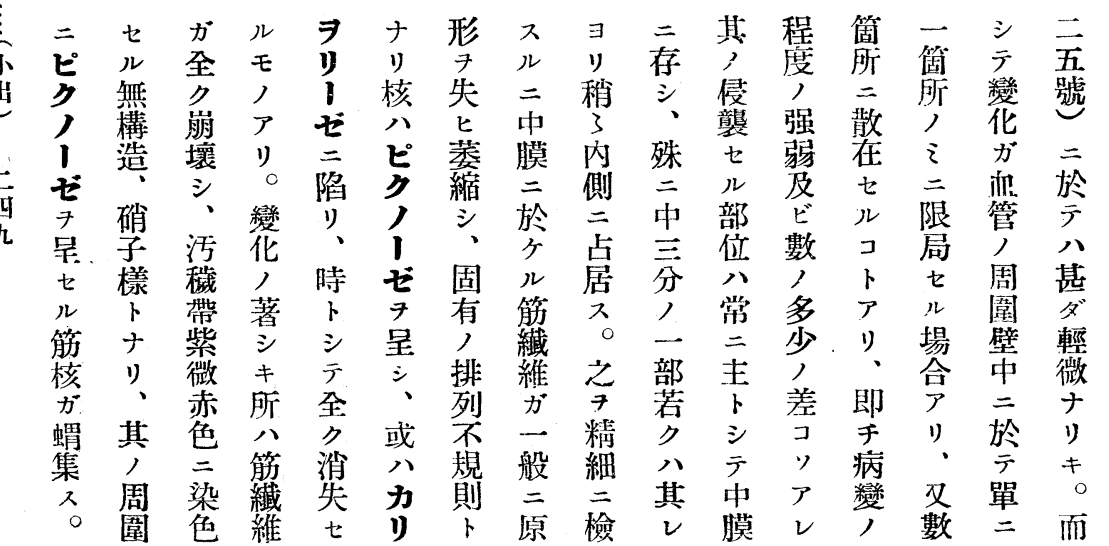




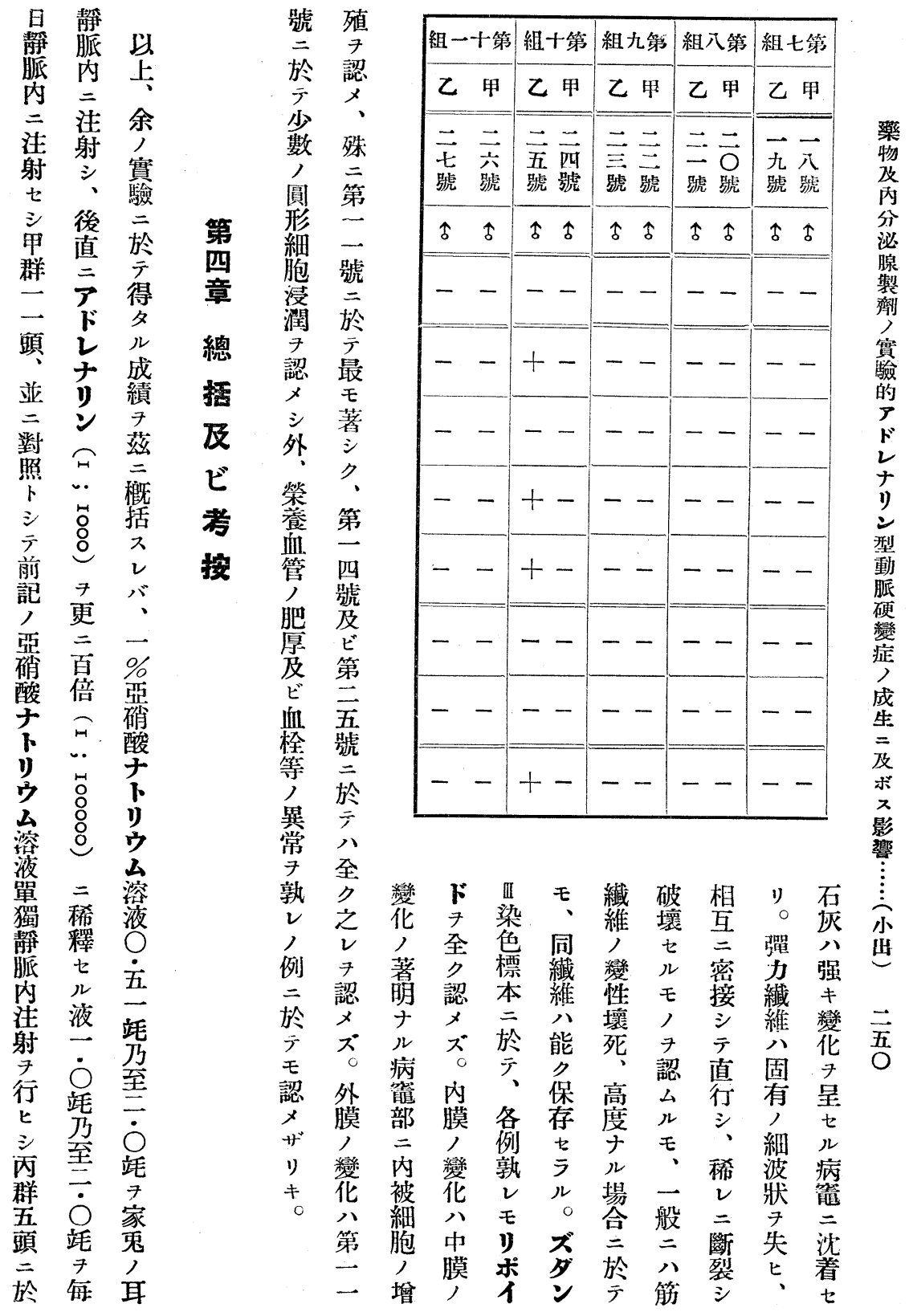




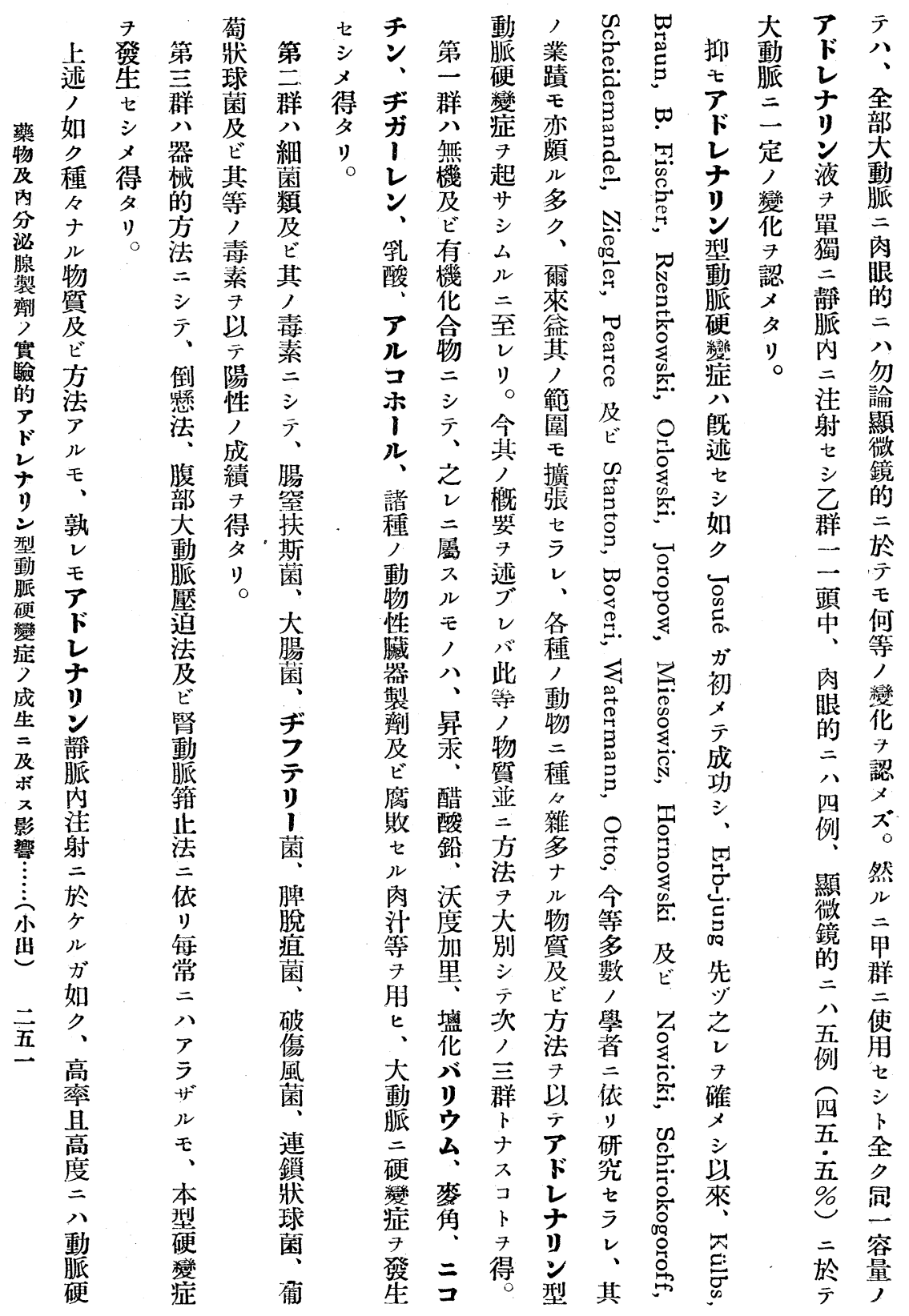




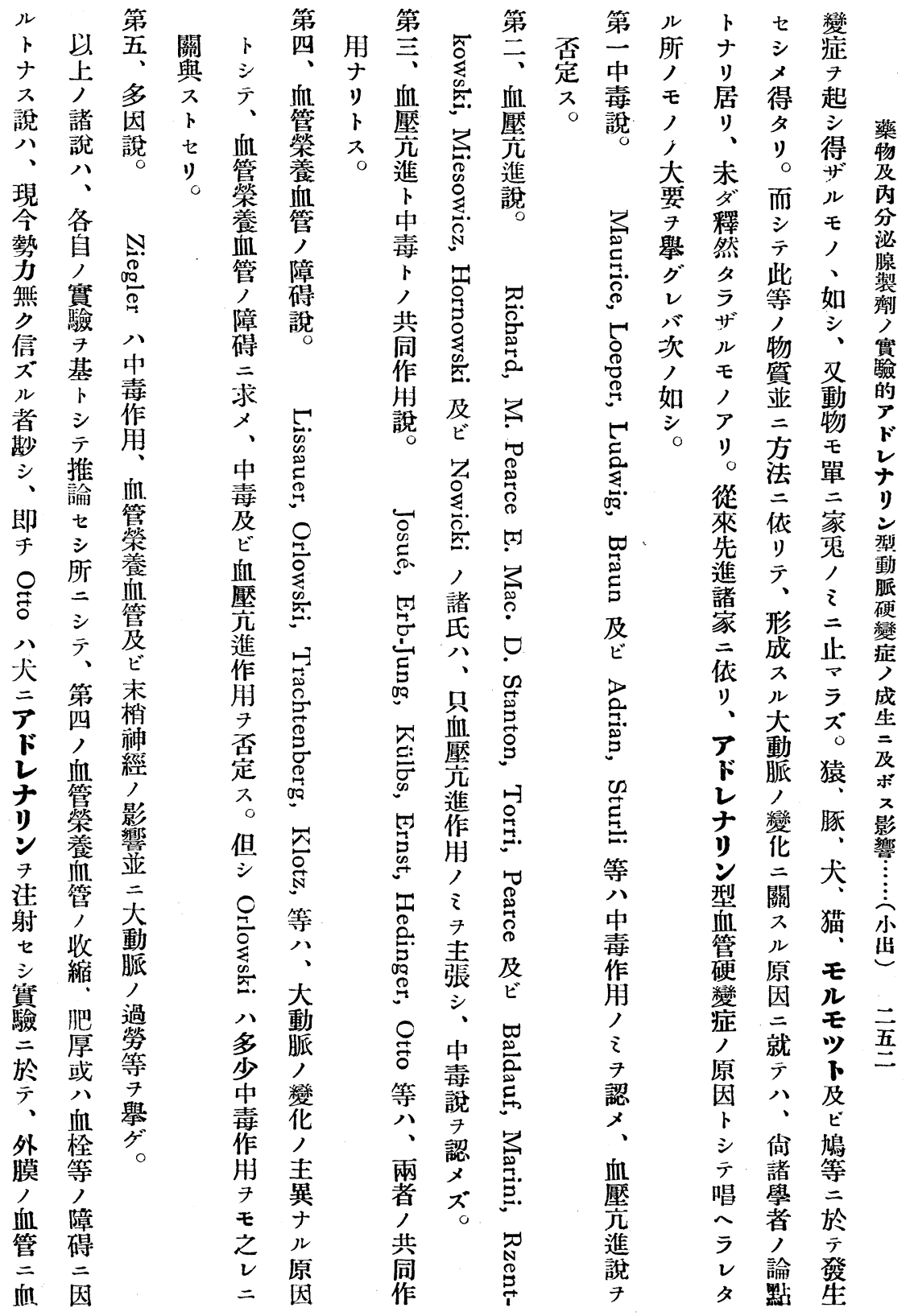




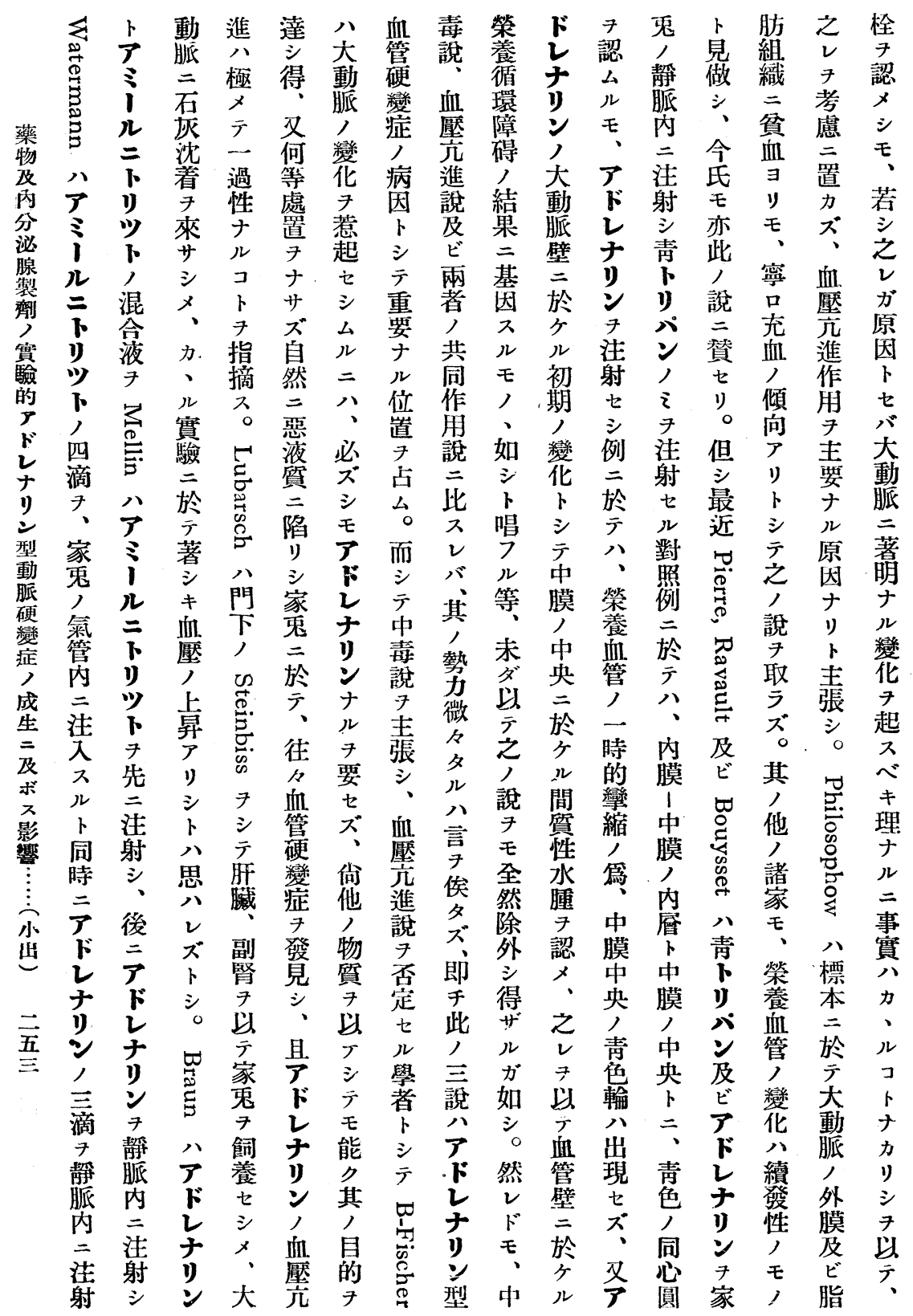




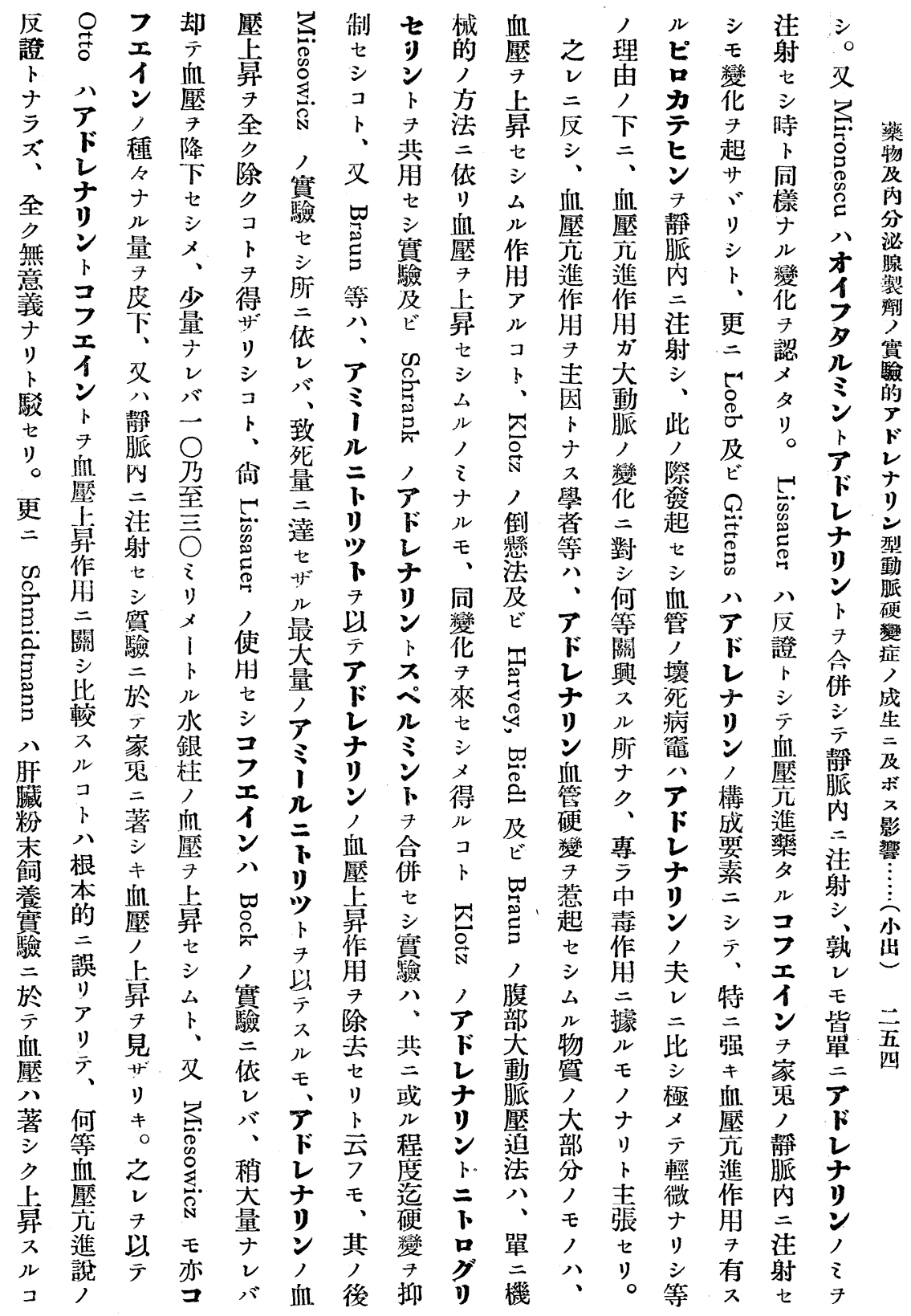




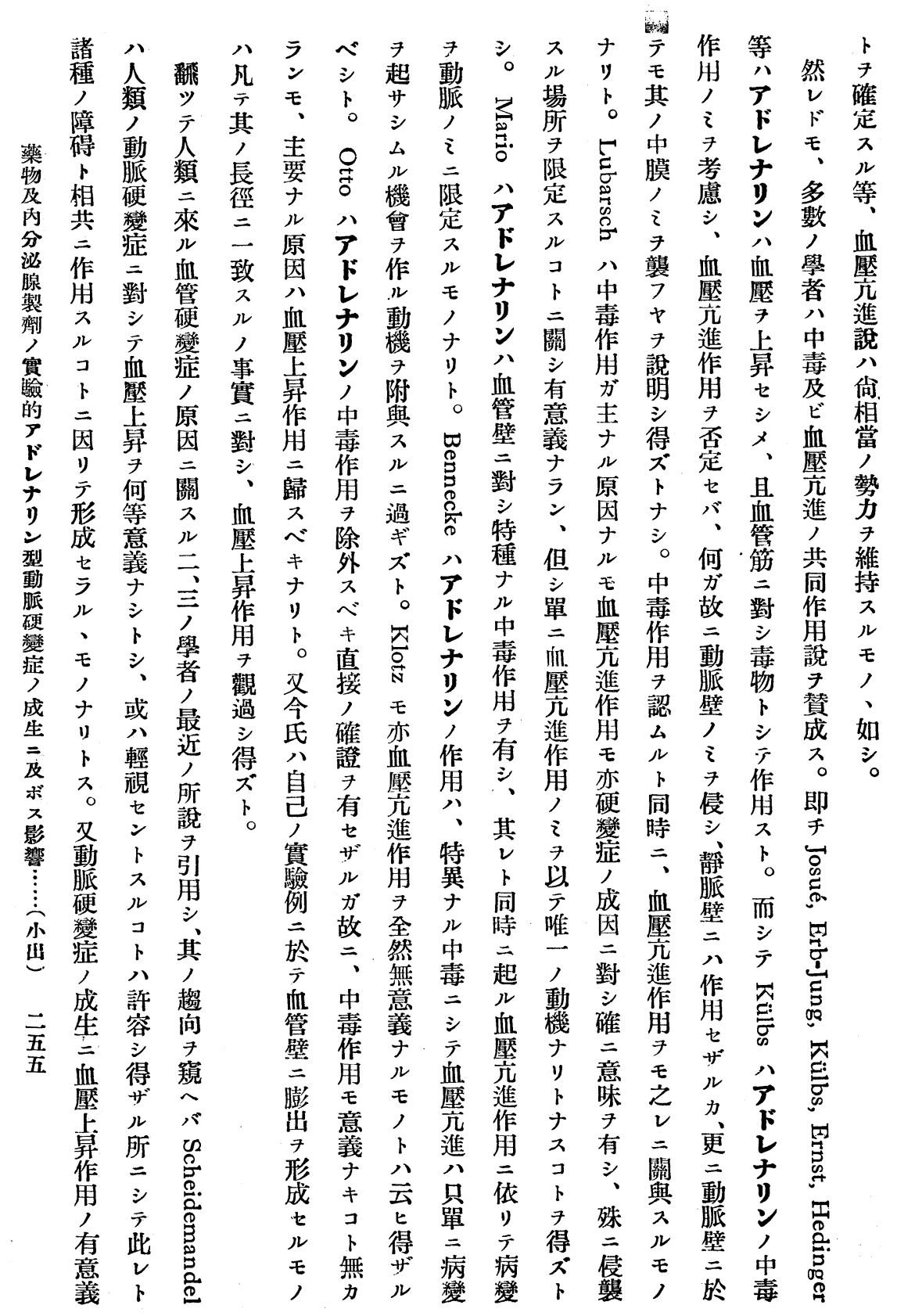




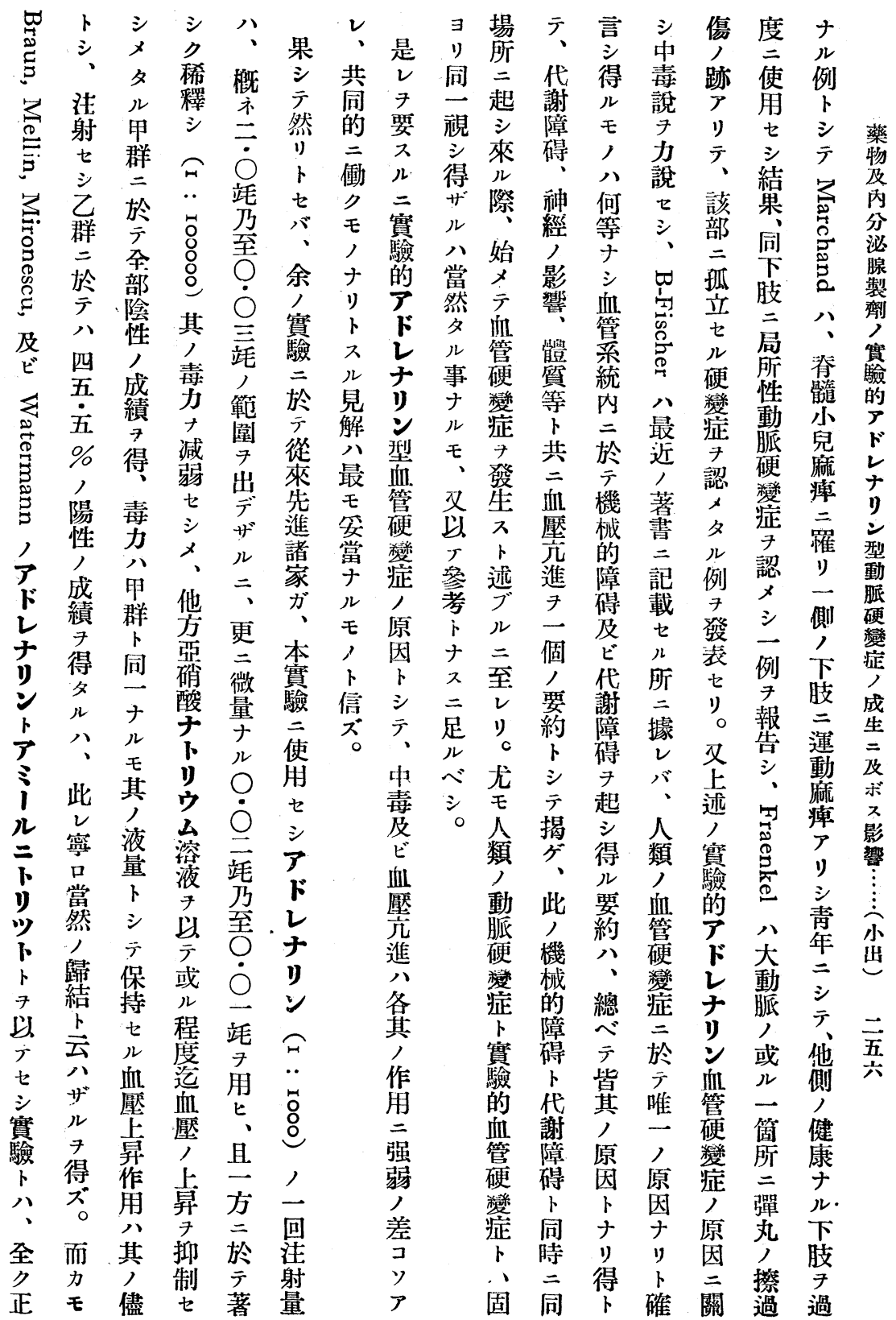




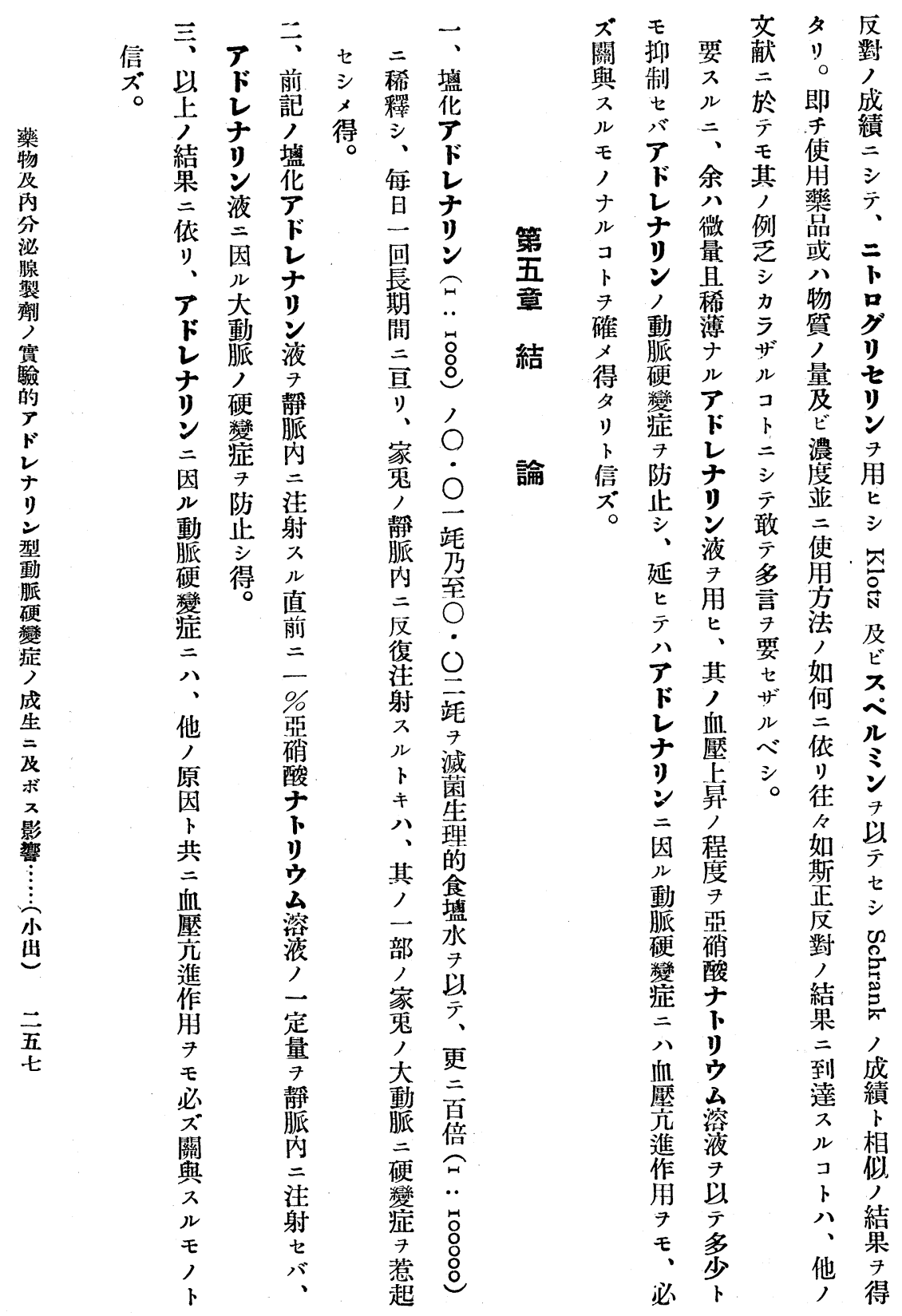




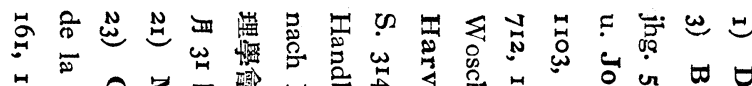

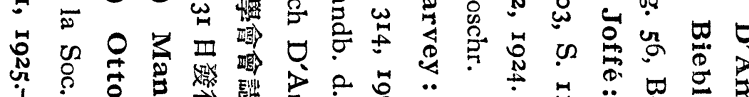

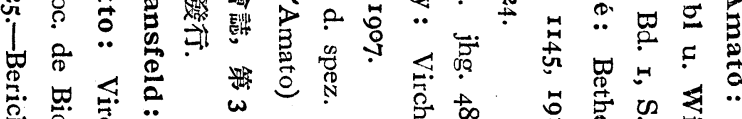

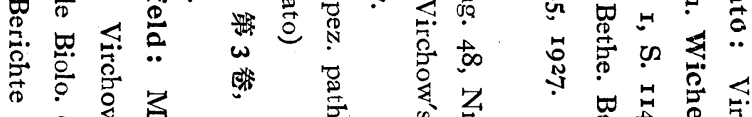

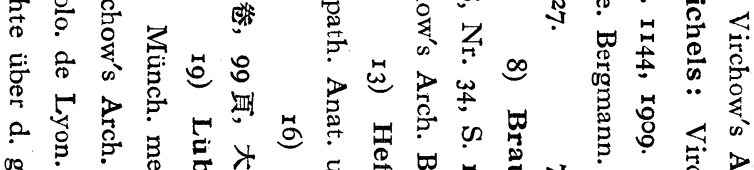

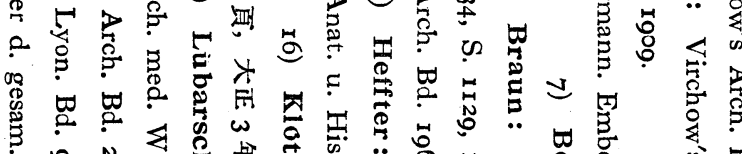

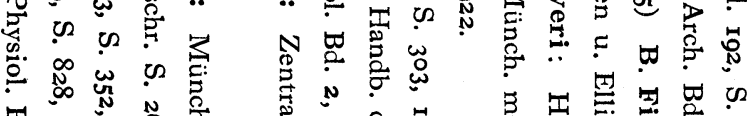

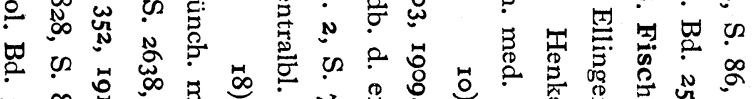

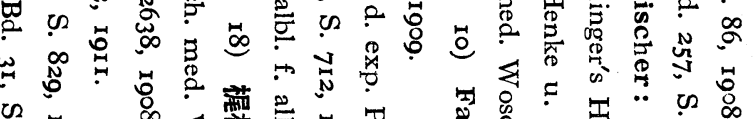

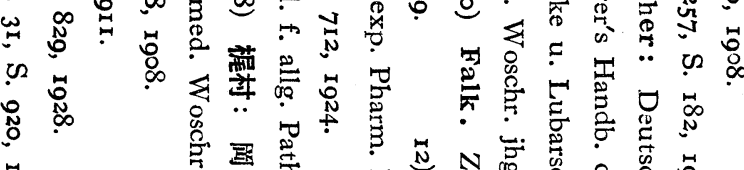

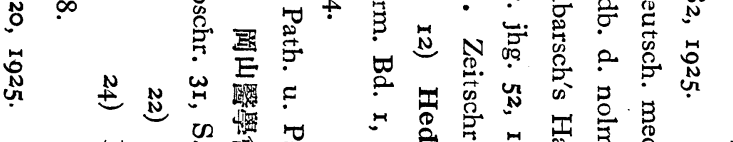

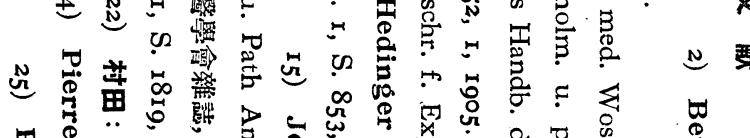

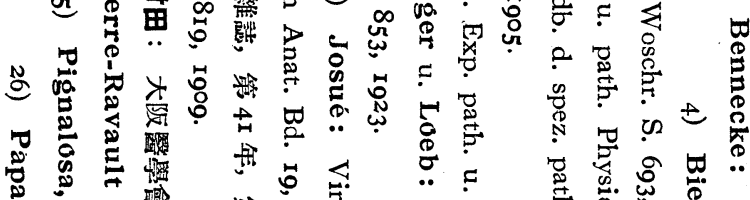

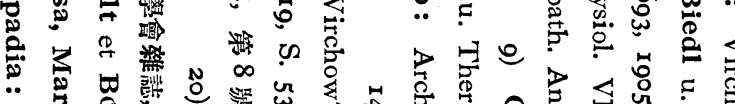

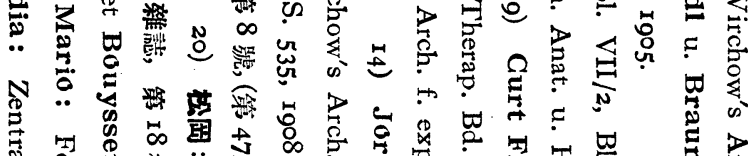

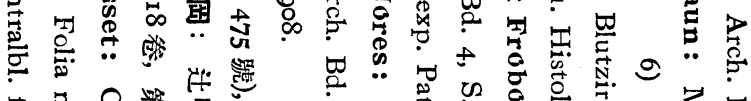

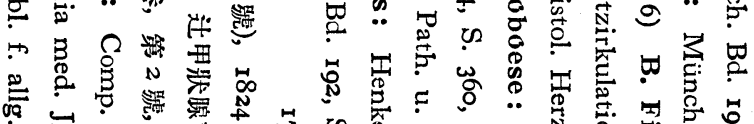

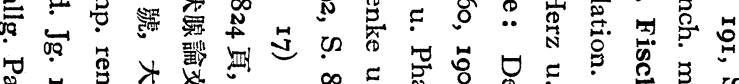

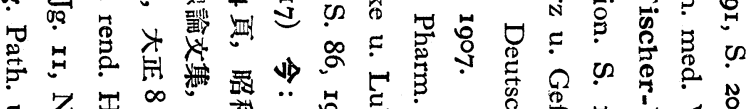
₹

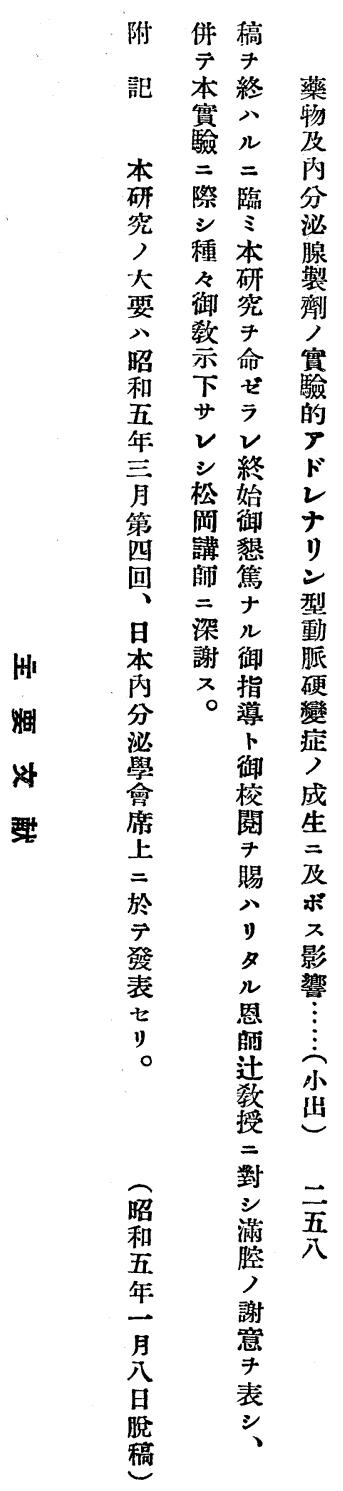

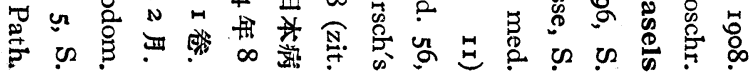




\section{第 第 第}

率 斷對面對面對 (3) (2) (1)

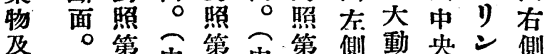

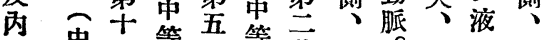

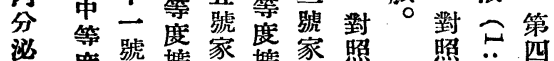

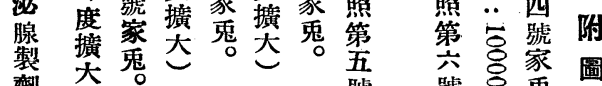

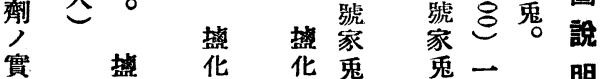

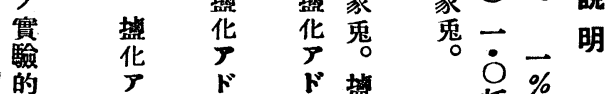

的

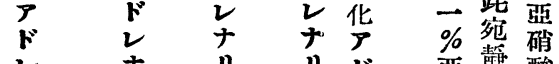

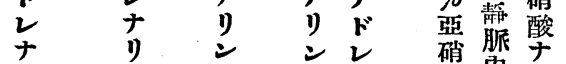

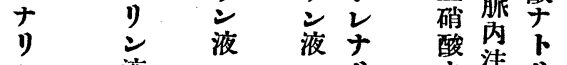

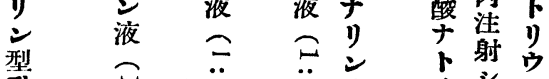

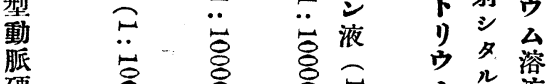

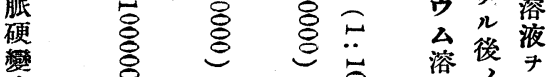

痗

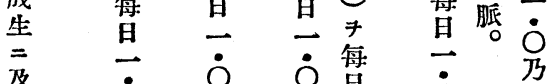

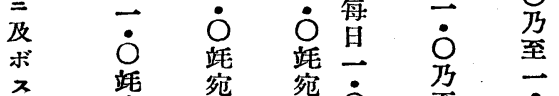

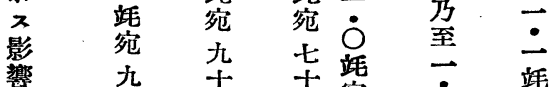

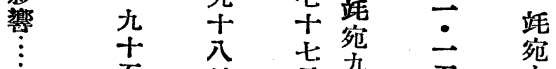

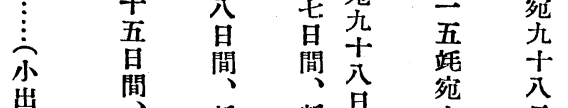

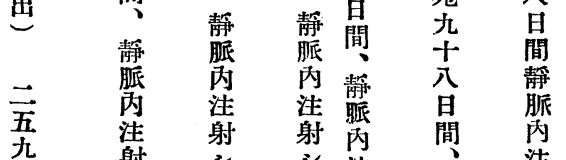

射 内

名射

後

天 後

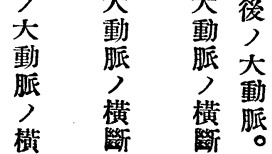

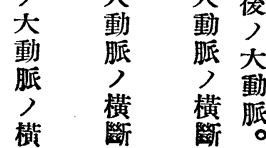

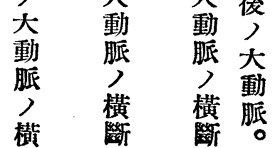

青

內

脈 䠿
後

射蓄

先

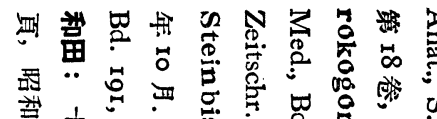

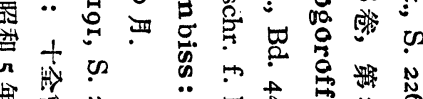
用呅

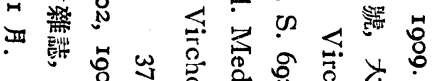

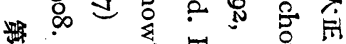

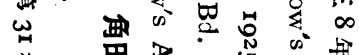

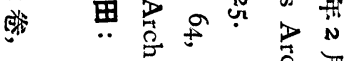

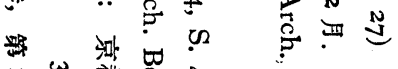

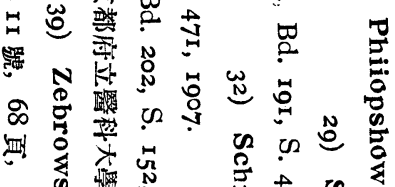

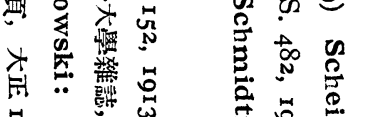

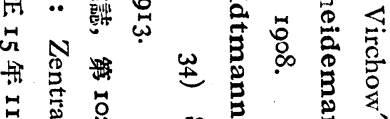

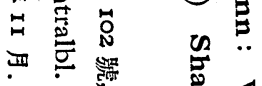
$+x$ w

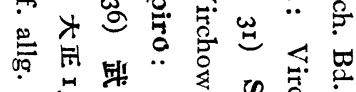

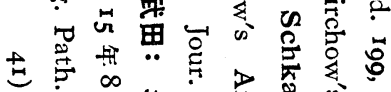

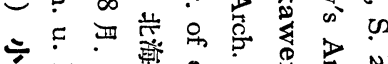

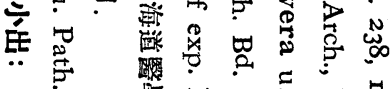

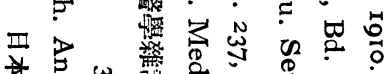

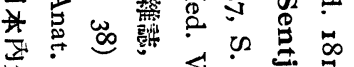

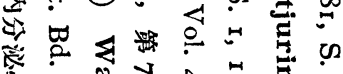
证

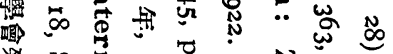

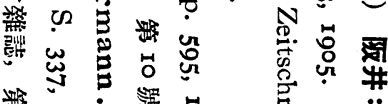

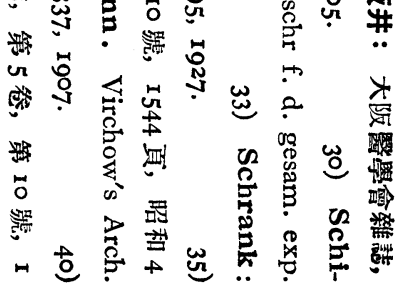




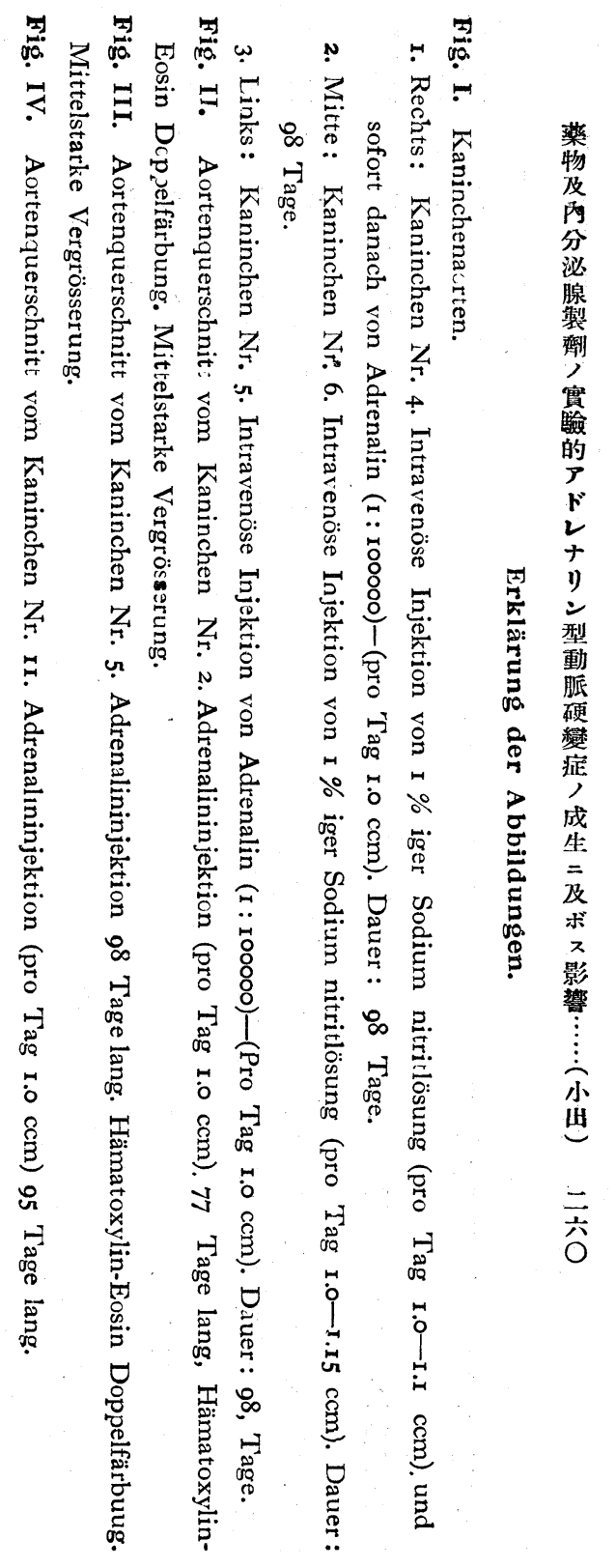


Fig. III.

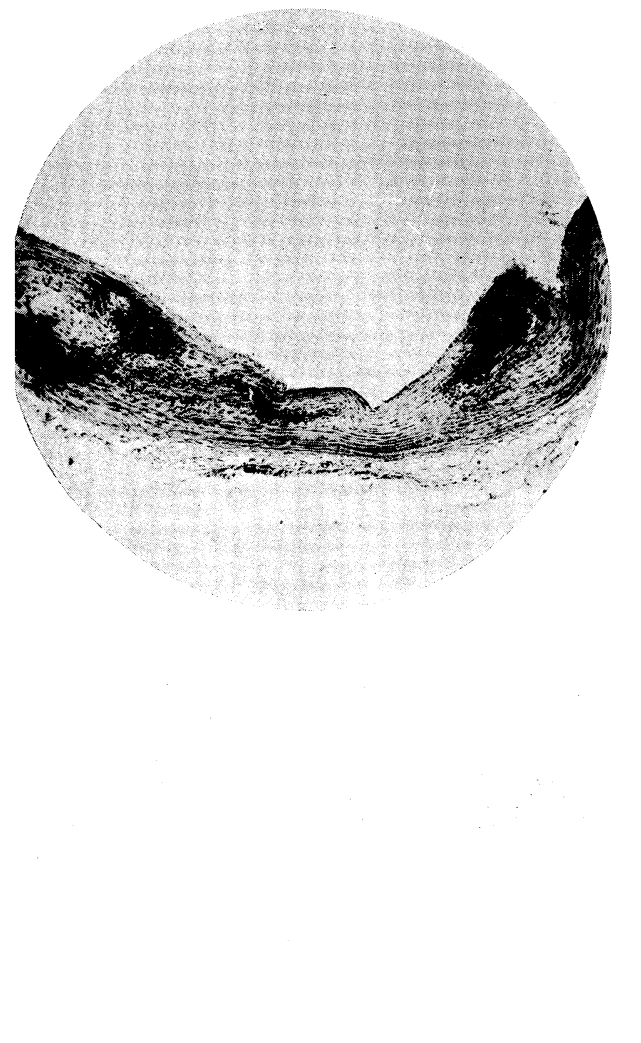

Fig. IV.

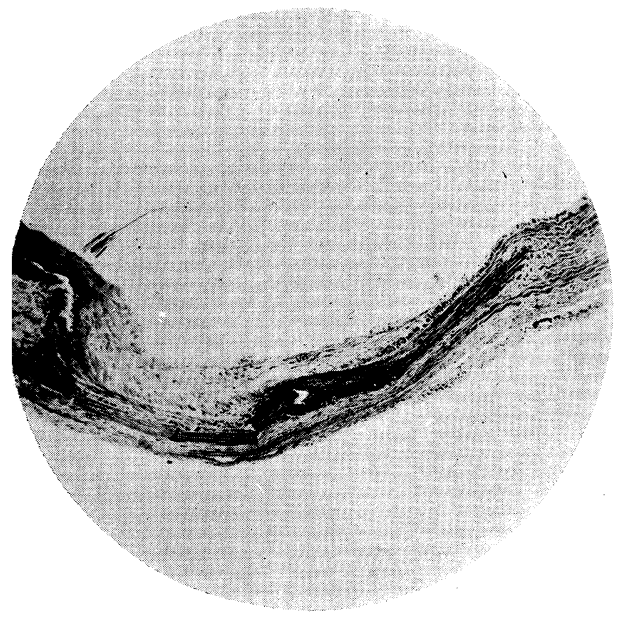

Fig. I.

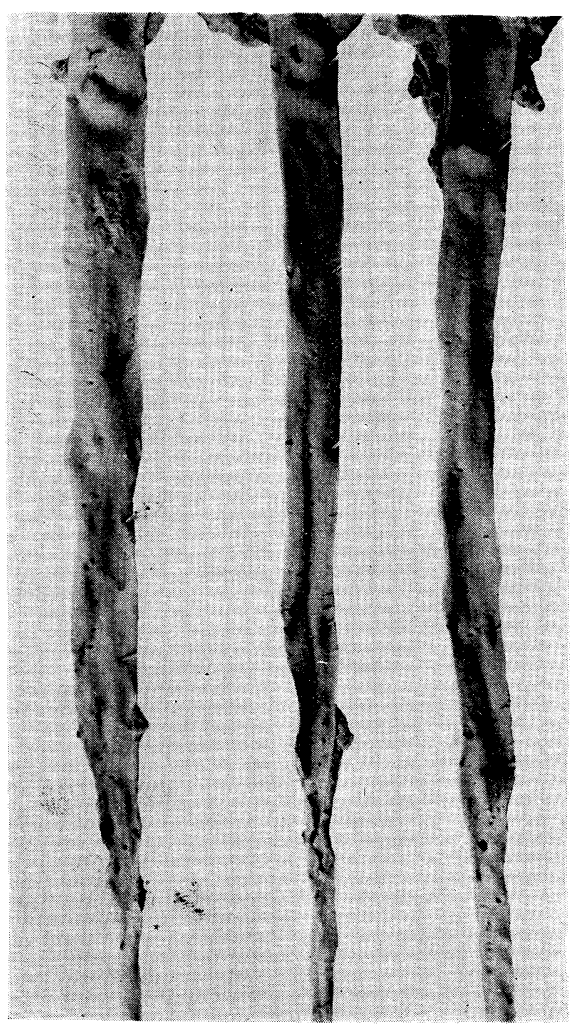

小 出 論 文 附 圖 Fig. II.

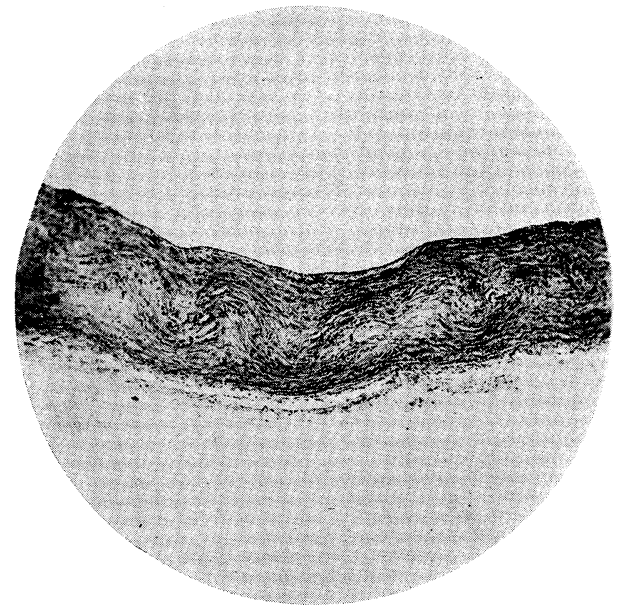


Schilddrüse auf die Meningenpermeabilität, indem er an dem mit Schilddrüse gefütterten oder thyreoidektomierten Kaninchen den Uebergang verschiedener intravenös eingespritzter Substanzen (Farbstoffe wie Uranin, Chrysoidin usw. oder Jodnatrium) in den Liquor untersuchte.

Die Resultate waren die folgenden :-

I. Bei dem mit Schilddrüse gefuetterten Kaninchen vermindert sich die Meningenpermeabilität für Uranin und Jodnatrium, und zwar besonders auffallend bei relativ lang durchgeführter Schilddrüsenfütterung.

2. Bei dem thyreoidektomierten Tiere neigt die Meningenpermeabilität für Farbstoffe und Jodnatrium zur Zunahmé.

(Autoreferat)

\title{
Ueber den Einfluss von Natriumnitrit auf die Entstehung der experimentellen Adrenalinarterionekrose.
}

\author{
Von \\ Dr. T. Koide.
}

(Aus der I. med. Klinik der Kaiserl. Univers. zu Kyoto, Japan.

Direktor: Prof. Dr. K. Tsuji.)

Nachdem der Verfasser als Vorprüfung mittelst Kymographions bestimmt hatte, dass die Adrenalinblutdruckerhöhung durch Natriumnitrit am stärksten unterdrückt wird, wenn man zuerst I \% ige Natriumnitritlösung und sofort danach die 100 fach verdünnte I \% ige Adrenalinlösung intravenös injiziert, stellte er die folgenden Versuche an.

Der Verfasser teilte 27 Kaninchen von ungefähr $2 . \mathrm{Kg}$ Körpergewicht in 3 Gruppen, nämlich eine A-B-und C-gruppe ein.

A-Gruppe: Tägliche Injektion von Adrenalin- u. Na-nitrit- 
lösung.

B-Gruppe: Tägliche Injektion von Adrenalin allein.

C-Gruppe: Tägliche Injektion von Natriumnitrit allein.

Versuchsdauer : 4I bis II 2 Tage.

Die Resultate: Aortenveränderungen finden sich nur in der B-Gruppe (makroskopisch 36\%, mikroskopisch $45.5 \%$ ), während die Kaninchenaorten in Gruppe A u. C völlig intakt sind. Diese Ergebnisse stehen im Gegensatz zu denen von Braun, Waterman, Miróneuscu u. a. Der Verfasser überzeugte sich, dass die Blutdruck erhöhende Wirkung des Adrenalins bei der Entstehung der: Adrenalin-Arterionekrose mit der toxischen Wirkung des Adrenalins in einen gewissen Zusammenhang steht.

(Autoreferat)

Ueber den Verteilungszustand der Elektrolyte bei künstlich erzeugter Serumanaphylaxie und den Einfluss der Schilddrüse darauf.

II. Mitteilung : Ueber den Einfluss der Schilddrüse auf den Kalium- und Galciumgehalt in verschiedenen Geweben bei künstlich erzeugter Serumanaphylaxie.

Von

Dr. S. Itoh.

(Aus der I. med. Klinik der Kaiserl. Univers. zu Kyoto in Japan. Direktor: Prof. Dr. K. Tsuji.)

An den Meerschweinchen, die der Verfasser in der vorigen Mitteilung gebraucht hat, untersuchte er diesmal weiter den Kalium- und Calciumgehalt im Gewebe von Herz, Lungen, Leber Nieren, Skelettmuskeln und Langröhrenknochen. 